OECD SME and Entrepreneurship Papers No. 23

\title{
Business advice for entrepreneurship and small firms
}

\section{OECD}




\title{
OECD SME and Entrepreneurship Papers
}

\section{BUSINESS ADVICE FOR ENTREPRENEURSHIP AND SMALL FIRMS}

\begin{abstract}
This paper examines international policy trends and issues in the provision of business development services (advice, consultancy, mentoring) to small and medium-sized enterprises (SMEs) and start-ups. It examines the rationale for policy intervention, different intervention models, recent evolutions in policy, and evidence on policy impacts. It focuses on three key challenges for business advice policy - how to stimulate demand for business advice from SMEs and start-ups; how to differentiate support to different types of SMEs and start-ups; and how to introduce online business diagnostic tools. The paper offers a number of recommendations to governments and SME and enterprise agencies.
\end{abstract}

JEL codes: L26, L53, M13, R58

Keywords: Business advice, business development services, entrepreneurship, start-ups, small and mediumsized enterprises, productivity, local development, regional development

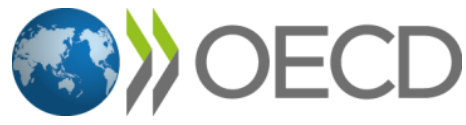




\section{ABOUT THE OECD}

The OECD is a multi-disciplinary inter-governmental organisation of 37 member countries which engages in its work an increasing number of non-members from all regions of the world. The Organisation's core mission today is to help governments work together towards a stronger, cleaner, fairer global economy. Through its network of 250 specialised committees and working groups, the OECD provides a setting where governments compare policy experiences, seek answers to common problems, identify good practice, and co-ordinate domestic and international policies. More information available: www.oecd.org.

\section{ABOUT THE SME AND ENTREPRENEURSHIP PAPERS}

The series provides comparative evidence and analysis on SME and entrepreneurship performance and trends and on a broad range of policy areas, including SME financing, innovation, productivity, skills, internationalisation and others.

This paper is published under the responsibility of the Secretary-General of the OECD. The opinions expressed and the arguments employed herein do not necessarily reflect the official views of OECD member countries.

The paper was authorised for publication by Lamia Kamal-Chaoui, Director, Centre for Entrepreneurship, SMEs, Regions and Cities, OECD.

This document, as well as any statistical data and map included herein, are without prejudice to the status of or sovereignty over any territory, to the delimitation of international frontiers and boundaries and to the name of any territory, city or area.

\section{(C) OECD 2021}

You can copy, download or print OECD content for your own use, and you can include excerpts from OECD publications, databases and multimedia products in your own documents, presentations, blogs, websites and teaching materials, provided that suitable acknowledgement of OECD as source and copyright owner is given. All requests for public or commercial use and translation rights should be submitted to rights@oecd.org. You can copy, download or print OECD content for your own use 


\section{Foreword}

This paper examines how governments and development agencies can strengthen business development services for small and medium-sized enterprises (SMEs) and start-ups to improve their growth, survival and productivity performance. Business development services cover a range of business advice, consultancy, coaching, mentoring and management training services offered by public or private sector suppliers. These services can help entrepreneurs and small business managers to identify where they need to improve their businesses and the steps they can take to do so. Governments often encourage the use of business development services in conjunction with financial support to new and small firms for objectives such as investment, innovation or exporting, with the aim of increasing the effectiveness of such support.

Business advice policy is a long-standing and standard area of public enterprise development intervention. However, policy makers today face several challenges - including persuading firms of the value of taking advice, matching demand and supply, ensuring high standards of support delivered, and achieving costeffective impacts. Governments internationally are applying new approaches to address these challenges. This paper takes stock of these developments and draws lessons. It focuses in particular on three issues:

- Building up demand for business development services from SMEs and start-ups, for example through raising awareness, increasing quality and improving matching.

- Providing targeted support for different types of SMEs and start-ups responding to identified differences in their needs.

- Exploiting the opportunities of digital technologies for to offer new and small businesses a basic diagnosis of their potential improvement areas.

The paper has been approved for publication by the OECD Local Employment and Employment Development (LEED) Committee at its $75^{\text {th }}$ session (CFE/LEED(2019)14). 


\section{Acknowledgements}

This paper was produced by the OECD Centre for Entrepreneurship, SMEs, Regions and Cities (CFE), under the leadership of Lamia Kamal-Chaoui. The work was directed by Jonathan Potter (Head, Entrepreneurship Policy and Analysis Unit, SME and Entrepreneurship Division, CFE, OECD), and David Halabisky (Policy Analyst, Entrepreneurship Policy and Analysis Unit, CFE, OECD).

Written contributions were provided by Kevin Mole (University of Warwick, United Kingdom), David Halabisky (OECD), Steffen Korsgaard (University of Southern Denmark, Denmark, and University of Oslo, Norway), Charlotte Norrman (Linköping University, Sweden) and Pedro Manuel Saraiva and Luís Viegas Cardoso (University of Coimbra, Portugal). The report was edited by Jonathan Potter (OECD). Comments and support were provided by Joshua Leedale, Cecilia Nyqvist, Andrew Paterson, and Stuart Roddam of the Department of Business, Energy and Industrial Strategy (BEIS), United Kingdom. Support was also provided by Sandra Hannig (Policy Analyst, CFE, OECD). Comments were provided by Karen Maguire (OECD) and Lucia Cusmano (OECD).

The paper makes use of contributions to an international expert workshop on business development services held by the OECD Centre for Entrepreneurship, SMEs, Regions and Cities (CFE) and the United Kingdom Department of Business, Energy and Industrial Strategy (BEIS) in London on 26-27 April 2018 and responses to an OECD survey of OECD member governments on the recent evolution of public business development services administered in 2018. 


\section{Table of contents}

Foreword 3

$\begin{array}{ll}\text { Acknowledgements } & 4\end{array}$

$\begin{array}{ll}\text { Executive summary } & 7\end{array}$

1 Policy issues and trends $\quad 10$

The nature and role of business development services and policy rationale 10

The nature of business development services 10

The role of business development services 10

The rationale for policy intervention 11

Policy delivery models 11

Trends in business advice policies 16

$\begin{array}{ll}\text { Decentralised, third-party delivery } & 16\end{array}$

Quality control and performance management systems 16

Digital business diagnostics and advice 17

$\begin{array}{lr}\text { Targeting and segmenting advisory services } & 18\end{array}$

Policy experimentation $\quad 19$

Evidence on policy impacts $\quad 20$

Challenges for business development services policies $\quad 21$

Stimulating demand for business advice by SMEs and start-ups 21

Providing well-targeted and appropriately-segmented business advice 22

Using digital technologies for business advice 23

Conclusions and policy recommendations $\quad 24$

2 Stimulating demand for business development services 25

Introduction 25

Constraints to demand for business advice 25

The characteristics of entrepreneurs may constrain advice taking 25

The structure of business advice support systems may constrain advice taking 27

$\begin{array}{ll}\text { Policy approaches to building demand for business development services } & 27\end{array}$

Building partnerships with private suppliers $\quad 28$

Simplifying the public business development services system 28

Leveraging existing touch points $\quad 28$

Limits to building demand for publicly-supported business advice 29

Recent policy initiatives to stimulate demand for business advice 29

Accreditation of business advice providers $\quad 29$

Account managers to improve matching of supply and demand 31

New access points to business advice 31

Conclusions and policy recommendations 32

3 Targeting and segmenting the business advice market 33

Introduction 33 
Firm-level distinctions for business development services 34

Innovation activity 34

Business lifecycle stage 36

Start-up origin 36

$\begin{array}{ll}\text { Social and environmental impact } & 37\end{array}$

Motivations 38

Recent policy initiatives for targeting and segmenting business advisory services 38

Introducing new targeted programmes 38

Organising services according to business needs 38

A step-wise support approach 39

Conclusions and policy recommendations 39

4 Digital business diagnostic tools $\quad 41$

Introduction 41

Policy issues in the development of digital diagnostic tools $\quad 41$

The benefits of digital business diagnostic tools $\quad 41$

The role of public policy 42

Examples of digital business diagnostic tools

Generic tools 43

Domain-specific tools $\quad 47$

Conclusions and policy recommendations

$\begin{array}{ll}\text { References } & 55\end{array}$

\section{Tables}

Table 1.1. A taxonomy of different approaches to business development services programme delivery $\quad 13$

Table 4.1. IMP3rove Digital Innovation Quotient Components 48

Table 4.2. Dimensions assessed in the COTEC Portugal Innovation Scoring tool 50

\section{Figures}

Figure 1.1. A long causal chain of connections 20

Figure 4.1. Competitiveness profile obtained from EAS online assessment tool 44

Figure 4.2. Example of future SME capability diagnostic results for a hypothetical firm 46

Figure 4.3. Building blocks of the Smart Industry Readiness Index 50

\section{Boxes}

Box 1.1. Business development services policy in Denmark $\quad 15$

Box 2.1. SME Wallet, Flanders, Belgium 30

Box 2.2. Business Development Services Database, Poland $\quad 31$

Box 2.3. Innovation Canada digital platform, Canada $\quad 32$

Box 3.1. The SMIL Business Development Programme, Sweden $\quad 35$

Box 3.2. Rural Growth Pilots, Denmark $\quad 37$ 


\section{Executive summary}

\section{Business development services are a common policy tool for supporting business productivity, growth and survival}

Business development services provide business advice, consultancy, coaching, mentoring and management training to start-up entrepreneurs and SME managers. They can support the strategic development and management capabilities of user firms, for example in human resources development, access to finance, and innovation practices. This can support productivity, growth and survival-enhancing activities such as technology adoption, exporting or digitalisation. Business development services are therefore often seen as one of the key policy levers available to governments to strengthen performance in weaker parts of the SME and start-up population as well as a tool to help more ambitious enterprises to meet their potential. Virtually all governments provide some kind of public support for business development services.

\section{Policy makers have various options to organise support}

Although the immediate delivery of business development services to SMEs and start-ups is often through the private sector, public policy normally plays an important role. The key contributions of governments include providing financial incentives for the use of the services and acting as a broker to match supply and demand. Business development services are frequently organised nationally, with common services and structures across the country. But there may also be local or regional differentiation of support, and it is common to offer face-to-face support through local and regional business development services centres.

Governments commonly provide subsidies for advice taking, channelled either to service providers or to user enterprises. Governments also often take a role in providing organising frameworks for business development services. This can include creating visible, coherent and quality-controlled public platforms listing service providers and facilitating connections to them for SMEs and entrepreneurs. It can also include supporting initial business diagnosis and subsequent signposting of firms to the right support and support providers. Governments commonly integrate business development services with other business support programmes such as incubators and access to finance.

There are many differences across countries in how public support for business development services is designed and implemented. Key distinctions are between approaches that are publicly-delivered or privately-delivered; nationally-uniform or locally-differentiated; supplied on-line, by telephone or face-toface; span all business development questions or focus on specific business development issues (e.g. innovation, exports, digitalisation, human resources); are offered to all enterprises or focused on specific types of enterprises/entrepreneurs (e.g. new start-ups, innovative firms, ambitious leaders); or are highlyintensive or light-touch.

Policy makers make choices in each of these areas and the differences in their approaches highlight the scope for system adjustments that could help to increase effectiveness and efficiency in different contexts. 


\section{Policy is evolving}

Internationally, public business advice policies are evolving rapidly. During the last decade, key developments include:

- Stimulating demand for services through vouchers, account managers, and new access points for SMEs and entrepreneurs.

- Splitting the diagnosis of business development problems in the firm from the delivery of consultancy projects to address them.

- Strengthening the quality control and performance management of publicly-subsidised suppliers.

- Unifying business advice offers in a single platform to increase system coherence and accessibility.

- Increasing targeting of services on firms with ambitions to change and absorptive capacity.

- Segmenting the business development services offer to respond to different needs, such as targeted programmes for women-owned businesses or SMEs in difficulty.

- Facilitating learning among peer groups of SMEs and start-ups with similar development challenges and ambitions.

- Systematising the use of business diagnostic tools to identify areas where entrepreneurs and SMEs can improve.

- Introducing digital technologies to offer self-diagnostics and basic advice to a larger body of SMEs and entrepreneurs at reduced marginal cost.

\section{Evidence on policy impact is mixed}

The findings of evaluations on the impact of business development service policies on SME and start-up performance are mixed. Results vary across a range of factors including the outcome measures of the evaluation (business growth, survival, productivity, innovation, exporting etc.), the design of the programme being evaluated (intensity of support offered, enterprise population targeted etc.) and the context in which it is operated (growth period, depressed area etc.). However, there are some areas of emerging consensus:

- Those enterprises/entrepreneurs that decide to avail themselves of business advice tend to perform better than the average both before and after intervention.

- The demand for business advice tends to be within the "comfort zone" of the SME or start-up, i.e. on issues they have already identified, at times of their choosing and through trusted contacts such as their accountants.

- The likelihood of the firm acting on advice received depends on its ability to absorb new ideas and implement changes, including its management knowledge and commitment and financial resources.

- Policies for business advice have better results on increasing firm output and productivity than on increasing employment.

- The policy impact per unit of public cost tends to be greater when more substantial support is provided (i.e. intensive programmes) than for light-touch advice.

- The way that programmes are implemented may have a large impact on the outcomes.

It is therefore important for policy makers to carefully consider the design and implementation arrangements of business development services interventions and to learn from previous experience. Further analysis is needed in specific countries to assess their business development services systems on the key dimensions of policy identified in this paper and to identify areas for improvement in line with lessons from international experiences. 


\section{Policy recommendations}

This paper makes a number of recommendations for public business development services policies, including the following:

\section{Building demand}

- Create and maintain a coherent national business development services platform with a recognised single brand.

- Offer advice at business development "trigger points" when demand for advice is greatest, such as times of market change or rapid growth for the firm or threats to the firm's survival.

- Exploit existing business "touch points" (i.e. occasions when firms interact with professional service providers) by collaborating with banks and accountants already working with SMEs and start-ups to link them to sources of business advice.

- Increase the use of existing business networks and peer-to-peer learning approaches for delivering business advice to SMEs and start-ups.

\section{Segmenting advice}

- Target more intensive and costly advisory services on businesses with growth ambitions and management capabilities to implement change (commonly start-ups, knowledge-intensive firms and firms seeking exports).

- Offer cost-effective advice to low-productivity SMEs and start-ups on management basics, driven by the enthusiasm of the manager to take part.

- Focus the initial advice to SMEs and entrepreneurs on issues identified as of immediate interest to them, such as enhancing product quality, customer service, or personal development, offering an entry point to follow-up support in other areas of company development.

Using business diagnostic tools

- Introduce systematic use of business diagnosis tools as part of business development services systems to filter firms and channel them towards the most appropriate support for them.

- Develop and promote online forms of business diagnostic tools including benchmarking and selfassessment health checks to provide basic advice and to act as an entry point to the business support system, helping generate interest in more intensive advice and linking support to identified business development issues. 


\section{Policy issues and trends}

\section{The nature and role of business development services and policy rationale}

\section{The nature of business development services}

Business development services offer a range of "soft", non-financial support to SMEs and start-ups (Miehlbradt, 2002). The services focus on business advice, consultancy, coaching, mentoring and management training that aim to improve management knowledge and decisions. They do not provide "hard" or financial support such as grants or loans, although they can offer advice on where and how to obtain it. Training for management skills that may support the decision-making of the firm is often seen as part of business development services, but training for workforce skills typically is not.

There are various definitions of business development services. The International Labour Organisation (ILO) emphasises training, counselling and advice, developing commercial entities, technology development and transfer, information and business linkages. The World Bank IFC Programme on Women's Development emphasises "non-financial services and products offered to entrepreneurs at various stages of their business needs. These services are primarily aimed at skills transfer or business advice". The Committee of Donor Agencies for Small Enterprise Development (2001) stresses "services that improve the performance of the enterprise, its access to markets, and its ability to compete, including training, consultancy, marketing, information, technology development and transfer, business linkage promotion, etc., both strategic (medium to long term issues that improve performance) and operational (day-to-day issues)".

The services may be delivered to SME and start-up entrepreneurs and management teams in various different ways, e.g. by individual consultants, through business development centres, or integrated with the services of business incubators and accelerators. Furthermore, policy support for business development services is commonly combined with financial support to firms in the expectation of positive synergies (Piza et al., 2016; Mole and Capelleras, 2018; Fraser et al., 2002).

\section{The role of business development services}

In the productivity distribution of firms, between high-productivity firms at the frontier and low-productivity laggards, there is a long tail of poorly-performing SMEs and start-ups with low productivity and sub-optimal management practices. There are wide variations in the productivity of firms even within the same industry and country, and the weak performance of those in the tail of the productivity distribution is associated with significant economic welfare losses (Haltiwanger et al., 2000). A key aim of policies for business development services is to help address this problem by promoting the diffusion of better management practices among SMEs and start-ups.

A number of studies link the managerial practices of firms to their performance. Key studies in this respect include Huselid (1995), Ichniowski et al. (1997), Bloom and Van Reenen (2007, 2010) Awano et al. (2017), Ichniowski et al. (1997), Sels et al. (2006), Patel and Cardon (2010), Sheehan (2013), and Ichniowski and Shaw (1999), although these studies are not for SMEs specifically. There is also evidence of relationships 
between management practices and firm performance for small firms specifically, mainly from developing countries. For example, McKenzie and Woodruff (2015) show relationships between stock-keeping practices, the keeping of records and firm outcomes. In addition, field experiments in developing countries have shown that large benefits are available from the adoption of modern management practices, with gains from consulting of as much as $17 \%$ (Bloom et al., 2013).

However, management best practices are not widely diffused among SMEs and new firms (Attewell, 1992). Start-up entrepreneurs, for example, tend to enter an industry without fully understanding how well their business will perform or assessing optimal practices (Jovanovic, 1982; Baron et al., 1999; Baron et al., 2001). Over time they gradually learn about the quality of their business. Furthermore, a major barrier to the adoption of better management practices in SMEs is lack of information.

Business development services offer opportunities to support learning to improve management in new and small firms, enabling improvements in economic performance at aggregate level by reducing firm-level inefficiencies.

\section{The rationale for policy intervention}

Nearly all governments provide public support for business development services, even though there is some private supply. The public interventions may involve direct provision (through public sector consultants and public business advice centres) or indirect support for private provision (through subsidies for using business development services, brokering supply and demand, or accrediting publicly-subsidised business advice providers).

The underlying rationale for governments to step in is to address two main types of market failures in the business development services market.

- Missing information. SMEs and start-ups often find it difficult to identify a supplier of relevant advice. Furthermore, even if they have good awareness of sources of provision, they often harbour doubts about its value and reliability, particularly given that the quality and impact of advice can vary significantly across advisors and businesses (advice is an "experience good", which depends on the fit between the entrepreneur and the advisor; Spence, 1973). Firms find it difficult to identify trustable and high-quality suppliers without public brokerage and may require initial support to establish relationships with suppliers that demonstrate value to them.

- Positive externalities. Business advice generates positive externalities as a result of the growth, skills and innovation-enhancing projects that result. The presence of positive externalities can lead to sub-optimal levels of business advice take up (Wren and Storey, 2002).

Furthermore, the SME or start-up may only experience the benefits from taking advice in the long term, whilst they incur the costs and disruptions in the short-term (Bourke and Roper, 2017; Bourke and Roper, 2016; Drews and Hart, 2015). Public support may therefore be required to get over short-term concerns.

\section{Policy delivery models}

Governments support business development services in a number of different ways. The interventions include subsidies to service providers or users, running publicly-branded business advice platforms with accredited and trained consultants, organising "sign-posting" to direct SMEs and start-ups to appropriate private-sector providers, offering connections to public support for implementing advice (including financial support), and incorporating business development services within public support infrastructures such as business incubators and accelerators.

This paper proposes a classification of business development services policy approaches focused on differences in: 
- Locus of delivery (public/private/brokerage model). This refers to whether the programme is delivered by the public sector, delivered publicly with some private sector involvement or outsourced to a private-sector supplier with the public sector acting mainly as a broker between supply and demand, for example following a diagnosis.

- Level of delivery (national/local). This refers to whether it is a centralised national programme or differentiated at the local level.

- Types of contact with the client (face-to-face/telephone/on-line). This refers to whether advice delivery is local face-to-face (F2F), through telephone call centres, or all online.

- Content focus (generic/niche). This considers whether support is generic or focused on a niche, such as growth or innovation.

- Intensity (light-touch/in-depth). This considers whether the support available is light-touch or indepth.

- Uniformity (tailored/uniform). This considers whether the content is tailored to the individual business or uses a consistent "one size fits all" approach.

Countries have adopted different models for their business development services systems across these dimensions, and policy makers have choices to make in each of these areas when determining how to design and deliver their policy support. These decisions can have important effects on policy impacts.

Table 1.1 below situates a number of existing business development services programmes on this framework to illustrate the variations that exist in approach. For example, the Growth Houses initiative in Denmark focuses on delivering high-quality business development services to the niche of high-growth SMEs and start-ups. It involves an in-depth tailored approach using local franchises, which are monitored for their impacts. In contrast, Syntens Futurized Business in the Netherlands involves a place-based roadshow to provide light-touch innovation advice to a broad group of small businesses. 
Table 1.1. A taxonomy of different approaches to business development services programme delivery

\begin{tabular}{|c|c|c|c|c|c|c|}
\hline Programme examples & Locus of delivery & Level of delivery & Contact with client & Content focus & Intensity & Homogeneity of support \\
\hline $\begin{array}{l}\text { Regional Growth Houses } \\
\text { (Denmark) }\end{array}$ & Brokerage & Local & Face-to-face & Niche (growth) & In-depth & Tailored \\
\hline $\begin{array}{lr}\text { Syntens } & \text { Futurized } \\
\text { Business (Netherlands) }\end{array}$ & Public & National & $\begin{array}{l}\text { Telephone and face-to- } \\
\text { face }\end{array}$ & Niche (innovation) & In-depth & Tailored \\
\hline Moaf Centres (Israel) & Brokerage & Local & Face-to-face & Generic & In-depth & Tailored \\
\hline $\begin{array}{l}\text { Innovation } \quad \text { Norway } \\
\text { (Norway) }\end{array}$ & Public & National & Face-to-face & Niche (innovation) & In-depth & Tailored \\
\hline $\begin{array}{l}\text { Growth Hubs (United } \\
\text { Kingdom) }\end{array}$ & Brokerage & Local & Face-to-face & Generic & In-depth & Tailored \\
\hline $\begin{array}{l}\text { Be the Business (United } \\
\text { Kingdom) }\end{array}$ & Private & National & Online & Niche (productivity) & Light-touch & Uniform \\
\hline $\begin{array}{l}\text { Regional Growth Houses } \\
\text { (Denmark) }\end{array}$ & Brokerage & Local & Face-to-face & Niche (growth) & In-depth & Tailored \\
\hline
\end{tabular}


The variety in approaches is illustrated further through the business development services programme cases below:

- Australia. Publicly-supported business development services include a combination of information provision and online resources and more intensive support on issues such as business management, digital transformation and exporting. These are often organised at the national level, with complementary services provided by the sub-national governments and the private sector.

- Belgium. The regions are responsible for managing business development services. For example, Flanders has partnerships with private sector providers that are arranged through a public procurement process and businesses can access the support using a voucher system. Private sector providers are also central to the business development system in Wallonia. Since 2004, it has been streamlining the system and the number of operators has declined from 84 to 30 .

- Canada. The business development services offered by the federal government are provided by government departments and agencies, Crown Corporations (e.g. Business Development Bank of Canada), and Regional Development Agencies, which provide support services that are tailored to particular regions. In addition, the federal government provides financial support to non-profit organisations such as Community Futures, which operates 268 offices around Canada that provide small business services including loans, tools, training and events to people living in rural communities.

- Denmark. The municipalities are the main entry points into the business development services system. Business counselling is offered through seven regional Growth Houses (see Box 1.1). A new digital platform has been developed to help companies find the support that they need. The national government complements the municipal support with additional specialised services (e.g. assistance with exporting). 


\section{Box 1.1. Business development services policy in Denmark}

A key component of the Danish business development services system is a set of Regional Business Development Centres known as "Growth Houses" (Vaeksthus), which were established by local governments and are supported by the Danish Business Authority. Each Growth House offers to chart the growth opportunities for SMEs and start-ups and work in collaboration with private-sector and publicsector service providers to help them to realise their potential. They also design and promote a series of services targeting potential high-growth companies.

In addition, the Danish Business Authority offers information and guides for businesses, including.

- Virk Startvaekst: Information and advice for entrepreneurs and established businesses with growth potential; operated in collaboration with Regional Business Development Centres.

- Soeg stoette: A guide to public-sector schemes aimed at supporting business growth and development; part of Virk Startvaekst and developed with support from the European Union.

- Vaekstguiden: A guide to public-sector schemes that support business growth; part of Virk Startvaekst and developed with support from the European Union.

The Danish government initiated a reform of the business development system in 2018 based on four core principles:

- Highest possible quality and based on business needs;

- Digitalisation should be used to improve quality and access to support;

- The role of the public sector should be to offer support when a well-functioning private market does not exist;

- Publicly-funded business promotion services should be delivered by the private sector to the extent possible.

The reform seeks to reduce fragmentation in the system of business development services support. This includes reinforcing the seven Regional Business Development Centres as the entry points into the system and creating an online platform to provide basic information on business creation and development and an overview of the business support system.

- Finland. Publicly-supported business development services include information provision, advisory services, training, business consultation, and networking support. Businesses can also access services for the development, recruitment, and training of personnel. These services are delivered online, by telephone, or in-person at the national, regional, sub-regional and local levels.

- Ireland. The bulk of business development services are delivered through Enterprise Ireland. Enterprise Ireland provides a range of advice and mentoring support direct to high-growth and export-potential SMEs and start-ups. It also has a Service Level Agreement with each of the local government authorities, which provides the framework for Local Enterprise Offices to deliver business information and advisory services to a wider range of SMEs and start-ups in their local areas. It also has a Service Level Agreement with four Business Innovation Centres to support high potential start-ups. Despite the strong use of public actors in the delivery of business development services, the private sector is also engaged.

- Israel. SMEs in Israel have access to an array of business development services at subsidised prices through a large network of specialised consultants providing personalised support through a network of local Maof business development service centres. The centres are funded by the 
Small and Medium Business Agency (SMBA) but managed by private sector firms. Service providers are selected through a tender process.

- Norway. Norway operates a demand-driven business development services system. Support is delivered through Innovation Norway, the Industrial Development Corporation; the Research Council; and local government authorities at county and municipality levels. Support is mainly offered through larger schemes, and tailored to individual enterprises within general frameworks. All business development services are discretionary in the sense that enterprises may apply, but are not entitled to support.

- Poland. The main actor of the Polish business development services system is the national Polish Agency for Enterprise Development (PARP). As well as being responsible for creating a businessfriendly environment, it delivers a wide range of programmes for SMEs and start-ups, including support for internationalisation, training programmes and developing an innovation system.

- Sweden. Sweden delivers the bulk of publicly-supported business development services through Tillväxtverket, the Swedish Agency for Economic and Regional Growth. One of its key services is an online one-stop-shop (verksamt.se), which provides businesses with tools and information about available support (e.g. training, workshops), including at the regional level. The agency makes use of a system of vouchers to provide access to support delivered by the private sector.

\section{Trends in business advice policies}

\section{Decentralised, third-party delivery}

There has been a policy shift in OECD countries in recent decades away from direct public-sector delivery of business development services to an enabling role for the public sector, focused on supporting local third-party providers to deliver the services. In this approach, the public sector role is in publicising business advice, providing incentives to firms for using advice, diagnosing the advice needs of individual firms and contracting with third-party suppliers to deliver advice corresponding to diagnosed needs. ${ }^{1}$ The aim is for public interventions to enhance, rather than crowd out, private sector provision.

The "hub and spoke model" proposed by Lambrecht and Pirnay (2005) is one of the approaches often adopted. The public role is in the hub, providing an impartial diagnosis of the problems of individual startups and SMEs and referring firms to appropriate specialist consultants in private sector providers in local spokes. ${ }^{2}$ The Danish Regional Growth Houses and the Growth Hubs in the United Kingdom are examples of this type of approach.

\section{Quality control and performance management systems}

The effectiveness of business advice depends on a productive interaction between advisors and entrepreneurs and SME managers (Lipsky, 2010). However, variability in the quality of advisers and services could undermine these interactions. For example, when business advice is poorly delivered, many potential recipients can be discouraged from accessing advice for periods of up to ten years afterwards (Mole et al., 2017). The trend towards decentralised, third-party delivery has therefore been accompanied by an increased use of competitive contracting, quality control and professional development systems across the third-party providers to ensure good quality.

\footnotetext{
1 The trend reflects wider shifts toward an 'enabling state' driven by new public management thinking (Hood, 1995; Deakin and Walsh, 1996; Dunleavy et al, 2006).

2 It can be argued that, by contrast, the incentives of consultants are to diagnose problems for which they have a, often standard, solution (Clark and Fincham, 2002).
} 
Franchises are often awarded to private suppliers after a competitive bidding process to run specific services, potentially in specific regions, for fixed periods, as for example with the Maof Centre system in Israel. Incentive contracting can also be adopted as part of these approaches. Incentive contracting involves a payment-by-results component in public sector contracts, which increases the payments to suppliers conditional on generating specified programme outcomes. The aim is to promote innovation and improve policy implementation in this way.

Supporting professionalisation of business advisors is another route governments are pursuing for achieving quality standards. Professional bodies offer training and assessments of their members to ensure a high level of technical expertise and adherence to standards and rules. Governments may therefore encourage the development of professional organisations in business development services. For example, the International Council of Management Consulting Institutes has academic fellows and International Standards Organisation (ISO) standards for consulting (see https://www.cmc-global.org/). Governments can also take an important role in achieving minimum quality standards by accrediting the advisors eligible to work on publicly-supported programmes. For example, the United Kingdom's former Business Link programme required all programme advisers to be accredited.

Another approach is to monitor the performance of suppliers through user satisfaction ratings, an approach made popular with Internet shopping. One of the problems with business advice is that it may be a one-off purchase by the recipient, which increases the potential for opportunism by the supplier. Introduction of satisfaction ratings signalled by users can 'punish' transgressors. This type of approach has been introduced by the Polish Agency for Enterprise Development, for example, with users attributing ratings to suppliers that are shown on a digital database from which future users select their suppliers. More generally, the question "would you recommend this to a colleague?" is seen as a key metric for business development service quality (Reichheld, 2003).

\section{Digital business diagnostics and advice}

Governments are increasingly using digital technologies in support of business development services. Digital tools offer a number of potential advantages. Services provided electronically can reach larger numbers of businesses with lower marginal costs per firm than face-to-face services. Many entrepreneurs and SME managers are likely to turn first to the digital environment to search for information to respond to the business development issues they experience. Digital tools can be easy to use. Data can be incorporated to enable entrepreneurs and SME managers to benchmark their business performance against peers and against good practices as part of a self-diagnosis, which previous research has shown to be critical for business development (Jones et al., 2008). A digitised service may enable a better match of advisers and those searching for advice. And digital tools can point businesses towards sources of further advice, learning opportunities and business support, acting as an enhanced entry point into the business development services system.

There has been significant interest in introducing the digital diagnosis of business development needs and opportunities in SMEs and start-ups. This has tended to follow two main models:

- Benchmarking of the user firm with others in the industry on the basis of those factors that can be converted into metrics and then compared. Benchmarking has often covered particular areas of business operations, such as human resource practices, and has emphasised the financial performance of the business (Cassell et al., 2001). One of the reasons for public sector development of such tools is that there are network externalities in benchmarking such that one organisation will have an advantage. ${ }^{3}$

\footnotetext{
${ }^{3}$ See for example Benchmark Index (https://www.benchmarkindex.com/index.php).
} 
- Health checks invite entrepreneurs and small business managers to make self-assessment scores of their businesses on standardised measures. Such health checks might use a balanced scorecard model to gain a better understanding of the strengths and weaknesses of the business along a number of dimensions including finance, customers, internal processes and learning (Kaplan and Norton, 1992). One of the difficulties involves weighting the scores in a way that matches the firm's performance model and an alternative is to provide scores for different building blocks (Flamholtz, 2003; Flamholtz and Randle, 1990).

However, there are potential drawbacks of digital tools, which should not be considered as sufficient in themselves or independent of a broader business development services system. Digital services offer codified knowledge, which may be seen as the poorer relation to tacit experiential knowledge transferred face to face (Chrisman and McMullan, 2004). Face-to-face interaction allows a much greater degree of bespoke and nuanced knowledge transfer and facilitates the co-production of solutions by the firm and advisor (Rice, 2002). Furthermore, developing relationships between the advisor and the firm, and the development of "rapport", has been shown to be critical for knowledge transfer (Bennett and Robson, 1999, 2004; Dyer and Ross, 2007). Therefore digital business advice may suffer obstacles to achieving changing business practices in the SME or start-up. Further difficulties include reaching entrepreneurs and SME managers who are not already digitally-oriented in their business practices and guiding entrepreneurs and SME managers to the most useful of the myriad resources available on the Internet.

One of the difficulties for the benchmarking tools is to include the right comparison set of firms, since firms have different strategies and conditions even in the same sectors and territories. An issue for the digital health check approach is that without a critical-friend business advisor, the approach relies entirely on the manager's view of the business, which may lead to a lack of critical analysis. In a face-to-face context, an adviser can lead the conversation towards challenges.

Notwithstanding the drawbacks, there is a strong case for a public digital repository of management knowledge useful for SMEs and start-ups, since they are tackling common issues, are eminently capable of self-diagnosis (Bennett, 2014) and can make use of non-interactive knowledge to support their routinised activities (Roper et al., 2017). For example, online advice may provide an SME or start-up with useful information on how to develop a marketing plan (Mole et al., 2014; Chrisman and McMullan, 2004). On the other hand, where business development services need to build capacity in a way that disrupts the firms' existing routines or involves more holistic adoption of new management practices then more interactive face-to-face and individualised service delivery are likely to be needed.

\section{Targeting and segmenting advisory services}

There has been a general policy shift in target firms in recent years. This includes a greater focus on reaching higher-quality businesses (Greene et al., 2008; Nightingale and Coad, 2013). In particular, there are clear trends towards encouraging high-growth firms, with almost all OECD countries now having some policy support for this target group (OECD, 2013; Mason and Brown, 2013). The increased targeting of higher-quality businesses is largely based on the objective of increasing the economic impact of business development services programmes.

Business advice tends to have greater impacts on firms with greater motivation to change, ambition to grow and managerial capabilities (Mole et al., 2008; van Doorn et al., 2016). In particular, the commitment of top management is critical to change (Boon and Ram, 1998; Van de Ven and Poole, 1995; Chadwick et al., 2015).

At the same time, start-ups exit the market at high rates - only one-in-ten start-ups survive for fifteen years, but survival and growth prospects are significantly greater for firms that employ more than five people (Anyadike-Danes and Hart, 2018). It may therefore make sense to focus costly business development services on larger start-ups and SMEs and to those that have demonstrated some early 'survivability'. A 
further issue is that business development services may privilege some firms while displacing the activity of rival firms. One way to reduce the problem of displacement is to avoid targeting firms that only trade locally, and to offer advice focused on boosting innovation and exports. High-growth firms in particular contribute disproportionately to the economy (Autio and Rannikko, 2016; OECD, 2013; Feeser and Willard, 1990; Siegel et al., 1993; Smallbone et al., 2002; European Commission, 2011; Mason and Brown, 2013; Lee, 2014).

Various strategies can be used to focus business development services on firms with greater potential for economic benefits:

- Programmes can focus on responding to demand rather than active marketing and promotion, allowing firms to self-select into programmes and hence selecting more motivated firms.

- Programmes can be designed with contents that favour more ambitious and capable firms. For example, high-growth firms demand more leadership development support and programmes offering this are more likely to attract them.

- Programmes can also focus on providing more intensive programme support rather than the most basic business advice in order to help smaller numbers of firms to act on advice provided.

- A staged approach offering support conditioned on the development of the enterprise can also be used. For example, the NIY Programme of the Finnish National Technology Agency (Tekes) used performance indicators that participant firms needed to hit to stay in the programme (Autio and Rannikko, 2016).

In contrast to these approaches, it is problematic to seek to direct select high-growth firms into programmes based on observable pre-existing company characteristics, since leading indicators are poor predictors of future high growth (Anyadike-Danes et al., 2015) and since existing high-growth firms may be experiencing a temporary high-growth episode, which is unlikely to repeat (Anyadike-Danes et al., 2013). A notable study by Coad et al (2013) found growth patterns in new firms to be largely random. Derbyshire and Garnsey (2014) argued that variations in growth outcomes are not random, yet maintained a somewhat skeptical view of the ability of policy to really predict and produce consistent growth outcomes.

In terms of trends in targeting and segmentation, there has also been greater recent policy emphasis on providing more differentiated services and delivery approaches in line with the great heterogeneity of SMEs and start-ups (Nightingale and Coad, 2013; Storey, 1994). Adapting business advice to the heterogeneity of SMEs and start-ups reflects the different needs of different types of firms and the different impacts that advice can have on different types of firms. For example, Wren and Storey (2002) found that the United Kingdom's marketing initiative in the 1980s was effective only for firms between 5 and 50 employees, suggesting that that type of support might best be targeted on firms in that size range.

\section{Policy experimentation}

A further recent trend has been the use of policy experiments to improve outcomes of business development services policies (Banerjee et al., 2011). This includes use of insights from behavioural economics based on the idea that there may be ways for policy to "nudge" firm managers to undertake behaviours that might be socially beneficial as well as privately favourable (Thaler and Sunstein, 2008). A "nudge" prompts people to alter their behaviour although it does not force any change or provide any financial incentive. "Nudges" operate through choice architecture, by rearranging choices in such a way as to make it easier to choose the preferred "nudged" outcome. Be the Business in the United Kingdom provides an example in the area of business development services. This programme tries to give SME managers and entrepreneurs more realistic benchmarking information about the comparative performance of their businesses (Behavioural Insights team, 2017). When managers realise that other companies in similar positions are performing better, they may seek to improve their performance and be more enthusiastic for engagement with business development services. 
In parallel, some policy makers have expressed enthusiasm about conducting randomised control trials (RCTs) to assess the impact of small adjustments in policy design and delivery, including business development services policies (NESTA, 2017).

\section{Evidence on policy impacts}

Business development services policies are often seen as one of the key levers that governments have to improve productivity, survival and growth performance in the SME and start-up population. While they may not necessarily lead to growth, as many managers seek improvements within the business that are not necessarily growth enhancing (Achtenhagen et al., 2010), they do imply increasing productivity and survivability.

Figure 1.1 sets out a model tracing the links that may be expected between delivery of business development services and changes in firm performance (in terms of growth, survival and productivity) and some of the key moderating factors that can constrain or enable the process. The moderating factors point to the importance of taking account of different ways in which business development services policies are implemented in impact evaluations, since this impacts the outcomes (Piza et al., 2016; Sawang et al., 2016).

\section{Figure 1.1. A long causal chain of connections}

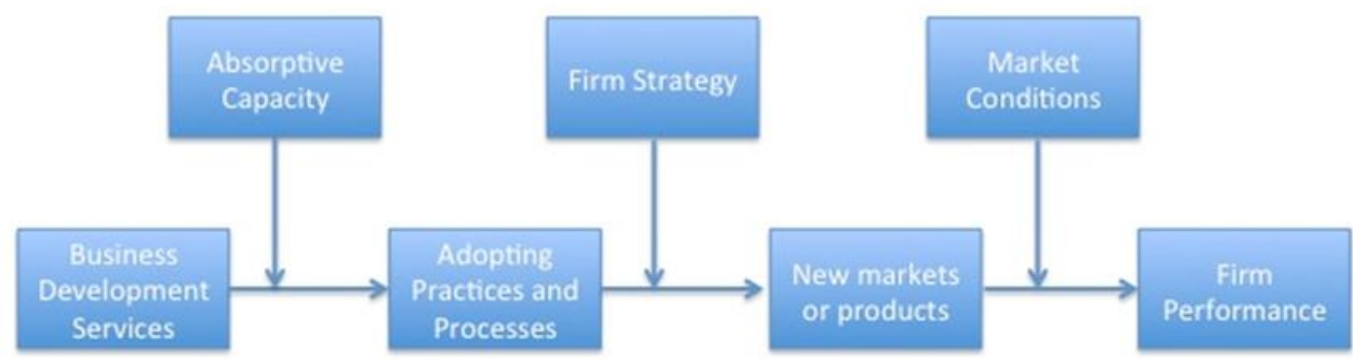

Source: Authors

The evaluation findings are mixed overall, varying across different types of services, different firm performance measures, different firm types and differing policy contexts. Several reliable policy evaluations provide evidence that business advice policies can improve SME productivity and growth performance (OECD, 2007). However, others have found zero or negative impacts. Furthermore, the evidence base as a whole suffers from important weaknesses related to the absence of control groups or allowance for selection effects in several studies. ${ }^{4}$ Selection bias is an important problem for business development services policy evaluations because those SMEs and start-ups seeking and taking advice are more likely to be already growing (Johnson et al., 2007), innovating and exporting (Bennett and Robson, 2003) and have greater management capabilities (van Doorn et al., 2016; Mole et al., 2008; Okhuysen and Eisenhardt, 2002). It may therefore be difficult to establish an appropriately matched control group of firms.

\footnotetext{
${ }^{4} \mathrm{~A}$ further potential issue is publication bias - i.e. that evaluations with positive impact findings may be more likely to be published and disseminated than those with negative findings. Piza et al (2016) produce a funnel plot and Egger test to estimate the extent of publication bias, suggesting publication bias effects for employment creation but not for other firm performance measures.
} 
The What Works Centre at the London School of Economics has undertaken a meta-evaluation of business advice policy impacts (What Works Centre, 2014), identifying reliable evaluations by adopting the Maryland scale (Madaleno and Waights, 2018). The work identified 23 reliable evaluations. Of these, 17 showed positive effects from advice. There were consistently better results for productivity and output than for employment, with mixed results for profits and exports. The evaluations also suggested that a "managed brokerage" delivery model outperforms a light-touch delivery model. This suggests a dosage effect, with higher doses of advice generating better outcomes after accounting for the extra cost (Mole et al., 2011). Other evidence supports this view, suggesting that where firms face an array of constraints they need a "big push" (Piza et al., 2016).

Overall, a number of key messages can be drawn from the reliable evaluations. These highlight that impact varies according to programme design and context and firm performance measures. There is a greater likelihood of positive impacts on productivity and output growth than for employment growth. Furthermore, the impacts appear to be greater when the support is of relatively high intensity and focused on businesses with better growth, innovation and export records and the absorptive capacity to utilise advice effectively. It is therefore very important for policy makers to consider alternative programme designs when establishing programmes.

It is also important to take evaluation concerns into account upfront in the design of business development services programmes. This includes establishing clear objectives and a theory of change for the intervention, collecting data against the pre-established objectives, and using more sophisticated evaluation methods to give a better picture of what works in business development services support. One avenue to pursue is to develop more randomised control trials (RCTs) as the most robust way to control unobservables, although it is important to pre-register the outcome measure that the randomised control trial is supposed to test. ${ }^{5}$ Although some randomised controlled trials have tested business development services programmes, they have most frequently been applied in less developed countries (e.g. Bloom et al., 2013; Campos et al., 2017; Drexler et al., 2014).

\section{Challenges for business development services policies}

Three issues are among the most important challenges for business advice policies, namely (i) generating take up of business advice by SMEs and start-ups; (ii) providing well-targeted and appropriatelysegmented business advice; and (iii) making use of new technologies to deliver some aspects of business developments services online. Each is discussed briefly below, and returned to in more detail in later sections of this paper.

\section{Stimulating demand for business advice by SMEs and start-ups}

One of the constraints for business development services is lack of demand from SMEs and start-ups. Lack of awareness of available services is a critical problem. For example, in 2019, only one-quarter of SME employers in England had heard of Growth Hubs, one of the government's major business advice operators. ${ }^{6}$ Needing to prioritise their daily operations, SMEs and start-ups often feel constrained in actively

5 RCTs themselves can nonetheless be associated with difficulties (Madaleno and Waights, 2018). Firstly,
contamination is an issue, particularly in the developed world. Whilst it might be possible to randomly allocate the
supply of a programme it is impossible to prevent the 'control' group members from seeking alternative methods,
particularly when their interest might have been piqued by an invitation to join a programme. Secondly, whilst the RCT
deals with internal validity, the external validity is weaker. For example, experiments in social entrepreneurship support
show what works in one context can fail in another (Tracey and Jarvis, 2007).
${ }^{6}$ Longitudinal Small Business Survey, 2019 SME Employers, Department for Business, Energy and Industrial Strategy 
seeking out advice. This becomes a particular issue where public business advice systems have complex structures and overlaps.

Furthermore, SME managers and start-entrepreneurs often doubt the ability of external advisors to add value to their decision making. In this, some of the traits associated with entrepreneurs may not be helpful in encouraging the take up of external business advice, such as desire for independence, overconfidence, and use of intuition. Firms may also be put off by the cost of investments (e.g. in innovative or skills projects), the loss of control and the increased managerial responsibilities needed to implement recommended actions.

In response, a nationally-recognised and trusted public business advice brand can build awareness of services and trust in their quality (Bennett and Robson, 1999; Greene et al., 2008). This can be encouraged by policy focusing on a single agency to supply or co-ordinate services. It can also be effective for policy to identify and support user firms through existing enterprise networks, such as regional clusters and chambers of commerce. The Cluster Innovation Programme in Norway has combined these two characteristics, for example, achieving a strong brand and awareness of services among SMEs and entrepreneurs in regional clusters, while the PLATO programme in the Netherlands provides business advice through peer firms.

Public support for brokerage between SMEs and start-ups and business advice suppliers combined with financial incentives for use of advice can also help create productive relationships, facilitating repeat use of business advice once value is demonstrated.

Working with the traditional trusted advisers of SMEs and start-ups, including their regular accountants and consultants or peer companies can also help introduce public programmes to SMEs and start-ups and to help overcome reticence in terms of trust in services.

Offering complementary support for taking actions based on advice, such as innovation and skills development projects, can also help overcome upfront concerns of some SMEs and start-ups about the costs of implementing advice.

On the other hand, it is important for policy makers to be careful in stimulating demand where the cost of providing the associated services is high. Research by the Danish government has shown that resistance to growth and risks of self-selection of "the wrong" SME managers into public programmes entail a significant risk of over-investments in public business development services programmes. Cost effectiveness is likely to be greatest where companies have ambition and potential to grow.

\section{Providing well-targeted and appropriately-segmented business advice}

A second challenge is to better target and segment business advice, given that successful business development services require the co-production of knowledge and solutions between advisors and participating firms. There are two components to this challenge:

- Offering support that matches the different requirements of different types of SMEs and entrepreneurs, achieving a good quality of fit between the support offered and the needs of the firm and between the advisor and the SME manager or start-up entrepreneur.

- Matching the intensity and public cost of the services to the public benefits that can be expected from supply to enterprises with different motivations and absorptive capabilities.

A common approach to tailoring involves designing different support for different stages of business development. For example, support could be tailored for nascent entrepreneurs, start-ups, established businesses, and businesses engaged in growth or internationalisation. Specific and tailored service offers can be developed for each company stage and marketed to firms in a targeted way. 
Policy can also be differentiated between ventures with high growth potential and established, lowproductivity SMEs. It has been noted that high-growth firms have particular potential for strong impacts. At the same time, however, it is relevant to support more established firms. These often have what Klofsten (1992) defines as a "business platform", i.e. a solid base of customers and a working organisation as a basis for potential future growth. These firms are not at the cutting edge of innovative production and business advice would be more appropriately focus on supporting catch-up process technologies and incremental changes to their products or business models. A key focus for these firms should therefore be on supporting management to get the basics right, for example introducing best practice management approaches or adopting digital technologies across the enterprise.

The cost and intensity of support can also be made to vary with enterprise growth ambition and potential. In particular, it can be useful for public business advice support to differentiate between more costly support to firms with high ambition and potential for productivity increase and less costly support to other firms that are nonetheless motivated to make changes in their practices. While the more intensive support is more costly, greater impacts are likely to defray the extra costs.

\section{Using digital technologies for business advice}

Digital tools are an increasingly common component of public business development services support. They have been developed and applied across a wide range of countries, including the USA, Singapore, Portugal and the Netherlands. However, care needs to be taken in introducing digital services, since they offer only generic advice. They are mainly suited to providing rapid diagnosis of business development challenges and pointing to basic guidance and sources of further information and support, for example as an entry point into business support systems.

There are two major categories of digital business diagnostic tool:

- Generic tools: These aim to assess the level of productivity and competitiveness of an SME or start-up in a certain sector or location. User companies enter key values for their own company (profits, number of employees etc.) and the tool provides a benchmarking of the company against records for other companies in the same sector or location.

- Focused tools: These aim at providing a diagnostic within a certain area of importance to companies, such as innovation, internationalisation or digitalisation, often using self-report information from key questions on business management practices.

The tools require relatively codified information from the user firms or benchmarking data sources. From this information they then produce generic advice. Compared with face-to-face support, they can be reactive and relatively passive, requiring the SME manager or entrepreneur to take the lead. On the other hand, they are useful in getting companies to start to think about their areas of strength and weakness, and in supporting them to use and make sense of the data they have on their own business.

Using a digital business diagnostic tool can be an important first step for entrepreneurs and SME managers to reflect upon their company's performance and practices vis-à-vis potential competitors and to focus on how to improve certain key aspects of their business approach, such as their innovation strategy or human resources development. After using a digital business diagnostic assessment, the user can be signposted to appropriate and tailored online advice.

Digital tools can also make business advice more inclusive and accessible. Online support makes basic business advice available with lower marginal cost than face-to-face advice, which opens up the possibility to expand reach to greater numbers of SMEs. In addition, more firms may be willing to engage with an online format where support is just "one click away". Moreover, as opposed to local business advice centres, online tools are readily available to firms regardless of location, even in remote areas, if internet access is available. 
Public policies can play several functions in the development and use of digital business diagnostic tools:

- Design: Developing a conceptual model that can inform the identification of business performance profiles and potential business development priorities.

- Data: The key business performance data used in digital business diagnosis tools often come from official sources, such as tax records, social security records, and official business surveys. Given public ownership of much of these data and public responsibilities with respect to data protection, government is well suited to take the lead in developing the tools, bringing in additional private data where relevant. Several countries have a single agency in charge of combining different administrative data and supporting their use. The development of a digital diagnostic tool could therefore be the responsibility of such an agency in collaboration with the government ministry responsible for enterprise.

- Dissemination: Public agencies can disseminate information on digital business diagnostic tools to SMEs and start-ups through a range of networks. A nationally-branded tool can achieve high visibility.

- Integration: Policy can also integrate several diagnostic tools (public and private) under a single user-friendly online platform that would provide an entry point towards a virtual toolbox or library of digital diagnostic tools for SMEs.

- Implementation: Even though an SME or start-up may undertake a digital diagnostic on its own, it may be important for policy to support them to implement actions responding to the diagnosis. This might be limited to providing information on potential actions to effect change. However, policy could also offer access to subsidised consultancy and mentoring by business advisors who make use of the diagnostic tool and build on its indications.

\section{Conclusions and policy recommendations}

Business advice policies aim to increase the strategic management capabilities of SMEs and start-ups to improve their growth, survival and productivity. This may increase economy-wide productivity by reducing firm-level inefficiencies in SMEs and start-ups operating behind the technology frontier.

Governments internationally are actively developing and implementing many new business advice policy approaches with potential lessons for others. Among the recent developments are decentralising services delivery, introducing performance management approaches for publicly-supported suppliers, using vouchers and managed brokerage to enhance take up, targeting and segmenting advice according to type of firm and using behavioural insights to nudge firms towards positive advice use.

There is still a lack of cumulative knowledge about what is most effective across the wide variety of approaches that governments are using and what will work best in which conditions. Nonetheless the following overarching policy recommendations can be offered:

- Stimulate demand for business advice. Introduce actions to increase demand for business development services based on creating a trusted brand, offering brokerage, using trusted contacts of user firms and offering support for actions to enact change.

- Provide well-targeted and appropriately-segmented business advice. Increase the targeting and segmentation of business advice policies corresponding to different profiles of SMEs and start-ups. This can be achieved by designing differentiated support for different life cycle stages of new and small businesses, targeting high-growth potential enterprises and low-productivity enterprises differently, and varying the cost of support with the level of ambition and capability of user firms.

- Use digital techniques for business diagnostics. Support the development and marketing of digital business diagnostic tools for SMEs and start-ups. Provide public support for the design, data inputs, promotion, integration with other services, and implementation of digital diagnostic tools. Consider digital tools as a first step in access to the business advice system. 


\section{Stimulating demand for business development services}

\section{Introduction}

A key challenge for business development services policies is to stimulate demand for and take up of advice from SMEs and start-ups. This may require policy responses to potential obstacles related to the characteristics of entrepreneurs and to the organisation of the public support system for business development services. This section considers these issues and the potential policy responses, touching on questions of how to:

- Build demand for business development services.

- Support businesses that would benefit from advice that do not get it.

- Get businesses to see the opportunity and overcome barriers.

- Nudge them into seeing what they need.

At the same time, it is important to recognise that the public sector should not over-invest in subsidising business development services recognising that many SMEs and start-ups are likely to continue to prefer to do without external advice and that provision of business advice may not translate into performance improvements in the firm, especially if the firm is not motivated to grow.

This section therefore highlights the relevance of building demand for business development services at two different levels - a low unit-cost generic support system aimed at all SMEs and start-ups and a more costly, tailored and intensive system for firms with stronger growth ambitions and capabilities.

The section draws on research insights and assessments of recent trends in policy practices, including insights from Denmark, where the public business development service system has recently been evaluated by a national expert commission and where guidelines for a revised system were released in April 2018, and from responses to an OECD survey of governments on policy developments.

\section{Constraints to demand for business advice}

\section{The characteristics of entrepreneurs may constrain advice taking}

There is various research evidence suggesting that taking advice and participating in training programmes benefits SMEs and start-ups (Mole and Capelleras, 2018; Mole et al., 2011; Seo et al., 2014). This might not come as a surprise when considering the complexities of running and growing a business. Many SME owners and entrepreneurs have strong practical or technical competencies, for example, but lack business and management skills. In practice, there are reasons why SME owners and entrepreneurs may not seek business advice. 


\section{Entrepreneurs who do not seek growth may not seek business advice}

Many entrepreneurs do not want to grow their businesses. This has been shown empirically in several studies of entrepreneurs (Davidsson et al., 2006; Wiklund et al., 2003). A recent study in Denmark has labelled this the "BMW syndrome", where entrepreneurs and SME owners stop pursuing further growth when the company becomes successful enough to pay for an expensive car and other goods associated with an attractive lifestyle (Gramtorp, 2018). The study suggested that there may be several reasons for this:

- Recruiting more people may be seen as involving "hassle" for the entrepreneur, if it requires more delegation, more managerial responsibility and less control over everyday operations and activities in the firm.

- Many entrepreneurs consider themselves specialists, enter their entrepreneurial career from a specialist background (e.g. engineer) and feel more comfortable in the daily operations and details related to products or sales than with strategic and managerial work.

- Many entrepreneurs consider the freedom of the small business to be valuable and are willing to limit business growth in order to maintain their experience of personal freedom.

Without the desire to grow, there is little incentive for entrepreneurs to take and act on external advice, given that it may generate costs and loss of control that many entrepreneurs would prefer to avoid.

Furthermore, growth may mean a different thing to entrepreneurs and policy makers. For policy makers, growth is primarily considered to be about the new job creation, sales growth or productivity growth at the firm level. However, for entrepreneurs and SME owners, growth is often a more complex and qualitative concept (Achtenhagen et al., 2010). For example, in the Gramtorp (2018) study, interviewed SME owners often referred to growth as becoming better at what they do, achieving higher levels of quality in their products, or personal development. Thus SMEs and start-ups that may be targets for business advice to policy makers because of low productivity, job creation or innovation, may well be considered as thriving by their owners and managers, who may prefer to continue to operate within their "comfort zone", allowing a focus on product quality, customer service, employee well-being or personal development.

In this context policy efforts may be needed to raise awareness of the benefits of employment, sales and productivity growth to more enterprises, to reassure managers about potential costs and loss of control or to target business advice offers on firms that are more likely to prioritise growth.

\section{Some entrepreneurial traits may lead to limited advice taking}

SME owners and entrepreneurs also appear to often have certain behavioural characteristics that may be expected to limit their seeking out of external advice and management training. In a review of the research evidence, Shane (2003) identifies a set of psychological and cognitive factors associated with a positive likelihood of engaging in entrepreneurship. These include:

- Desire for independence, which entails for example that you are willing to defy other people's judgment.

- Overconfidence, which entails believing in your own judgment without collecting evidence.

- Representativeness, which entails a willingness to generalise from small samples that are not representative.

- Intuition, which means too strong a belief in the accuracy of your judgement given the data.

As such characteristics are associated with a higher likelihood of becoming an entrepreneur, it can be questioned whether this group of people will be willing to spend time taking and advice and training based on what other people think that they should do. 
Bager et al. (2015) and Nielsen et al. (2018) have indeed found strong self-selection biases in enrolment to a EUR 15 million budget three-year Danish training programme for growth-oriented SME managers. Those SME managers who enrolled on the programme were better educated, younger and had less managerial experience. SME managers with more experience and less formal education were the least likely to seek the training.

The programme sought to enrol 600 SME managers. However, despite the provision of high-quality training free of charge, it struggled to recruit enough managers. Programme managers ended up relaxing the inclusion criteria to include SME managers who were not growth oriented, and were perhaps not even lacking in the relevant skill set. Instead the programme was used for other purposes such as networking and career advancement.

\section{The structure of business advice support systems may constrain advice taking}

A complex business development services support system is likely to constrain the demand for business advice from SMEs and start-ups by reducing visibility and trust in services compared with a nationallyrecognised system, by raising questions among entrepreneurs on where to find the best advice and by impeding the development of services in the best suppliers.

These issues were underlined by an evaluation of public support for the business development services system in Denmark in 2016 (Forenklingudvalget for erhvervsfremme, 2018; Ingstrup et al., 2017; McKinsey and Company et al., 2016). In total, there were more than 250 actors involved in the Danish business development services system, organised across three government levels (state, regions and municipalities).

This was associated with two problems. Firstly, there were significant overlaps in activities and programmes across different business advice suppliers. Examples included:

- Local services at the municipal level overlapping with specialised services at the regional level.

- Thematically similar projects undertaken in different regions in parallel.

- Overlapping cluster policy efforts.

From the perspective of the companies, there were too many access points into the system and public support services that appeared to be targeting similar firms and issues. This leads to inflated transaction costs for the companies when engaging with the public business development services system.

Secondly, it was more difficult to develop economies of scale and specialisation as well as consistent performance standards in a system with large numbers of small and dispersed suppliers. Further, there were indications that the services were driven more by supply than demand, i.e. driven by internal interests rather than customer demand or policy priorities (McKinsey and Company et al., 2016).

In addition, demand can be constrained in systems that are dominated by direct public sector supply. This is because public service providers are often perceived as of poor quality by SME managers and entrepreneurs compared with the private sector (Bagere et al., 2015) while direct public provision can also neglect the benefits of leveraging private sector specialisations and contacts.

\section{Policy approaches to building demand for business development services}

There are a number of ways for public policy to strengthen demand for business development services among SMEs and start-ups. Some key policy options are discussed below. 


\section{Building partnerships with private suppliers}

Public business development services suppliers can suffer from a number of disadvantages in generating demand from SMEs and start-ups compared with private providers. Public sector operators may have difficulties in competing with private sector operators for competent business developers and advisors. They may also have difficulties obtaining the same flexibility and agility as private sector operators, given that they operate under public governance arrangements. In addition, even when they are highly competent, public sector operators may struggle to achieve legitimacy with SME managers and entrepreneurs due to pervasive perceptions of public sector operators as inefficient and incompetent.

Therefore, rather than seeking to deliver business development services directly by public agencies, in many cases it will be better to collaborate with external private sector partners operating with public sector support. Private sector operators can achieve high levels of specialisation and legitimacy. Further, cooperating with private operators can lead to co-financing of business advice initiatives, combining public and private sector money, hence leveraging the impact of public expenditure and helping ensure that there is a real demand for the services supplied.

\section{Simplifying the public business development services system}

Rationalisation and co-ordination improvements in the public business developments services system can help build demand for business development services. The Danish government has gone forward in this direction, since its 2016 evaluation which identified the problems of complexity, by reorganising its business support system in 2018 in order to reduce the number of entry points to the system. A new digital platform indicates sources of support, regional level support has been re-organised into six business hubs providing business development services and links to specialised national services, each conceived as a one-stop shop for the region, and additional provided by municipalities needs to comply with the Decentralised Business Promotion Strategy to ensure consistency and avoid overlaps (European Commission, 2019). Measures of this kind can increase visibility, branding and referrals of SMEs and startups to appropriate advice.

\section{Leveraging existing touch points}

Research has shown that SME owners and entrepreneurs are more likely to take advice from people who are familiar with their businesses (Mole and Capelleras, 2018). Furthermore, building long-standing, trusting and knowledgeable relationships with SME owners and entrepreneurs is costly. Therefore engaging with the existing "touchpoints" of the SME or start-up - including their existing bankers and accountants - is potentially an effective and cost-efficient way of "nudging" SME managers and entrepreneurs towards the use of business development services that are useful to them.

As many of these accountants and bankers are experienced already, it should be possible to leverage their existing competencies. To support this, touchpoints could be offered training and tools to provide business advice to SMEs and start-ups with public support. For example, a "train the trainers" model could be used to cascade out competences and combined with an offering of basic common support tools such as business diagnostic tools. If these activities are integrated with the existing services of the banks and accounting firms, a certain level of cost sharing might also be achieved between the public and private operators. Alternatively, existing touchpoints could be engaged to assist in the identification of SMEs and start-ups with potential to take up business development services offered by other providers rather than be asked to provide these services themselves. 


\section{Limits to building demand for publicly-supported business advice}

An important caveat needs to be taken into account when considering how far to build demand for publiclysupported business development services - which can be summed up in the advice "Don't Over-invest"

The review of the Danish business development services system discussed above suggests that there is a significant risk of over-investments in business advice programmes for SMEs and start-ups. In part this reflects a problem of being able to channel public support to businesses would not seek relevant advice and training from professional consultants and where the input could stimulate growth. If not well-designed and targeted, business advice programmes can be extremely costly and may fail to realise their promise. For example, the programme reported by Bager et al. (2015) spent a staggering DKK 187000 (approximately EUR 25000 ) of public money per participant in the training programme. An evaluation of an early model of regional Growth House business development service centres in Denmark (væksthusene) found that they generated approximately 656 new full time jobs, but this effort involved 250 employees working in the centres; a good output but at a steep price (IRIS Group, 2013).

It is therefore important to consider the benefits and costs of different forms of business development services intervention. Provision of information on private sector supply, digital business diagnosis and brokerage and matchmaking services are relatively low (unit) cost initiatives. On the other hand, incubators and targeted training programmes for SME owners can be of high public cost and need strong benefits to justify their delivery. This underlines the need for a strong emphasis on evaluation in the field of business development services policies.

\section{Recent policy initiatives to stimulate demand for business advice}

Governments have introduced a number of policy initiatives in recent years that help to increase the demand for business development services by SMEs and start-ups. Examples are discussed below.

\section{Accreditation of business advice providers}

Flanders, Belgium, has been operating an SME Wallet voucher system for many years, which SMEs and start-ups can use to access training and business advisory services (Box 2.1). From 2016, a modification was made so that user firms are now directed to registered and accredited business development services providers. This modification should focus support on better-quality suppliers and increase the quality of the services received, hence increasing perceptions of quality and trust in services offered. 


\section{Box 2.1. SME Wallet, Flanders, Belgium}

The SME Wallet, operated by Enterprise Flanders, was launched in 2002 as an interactive online platform that enables SMEs to obtain between EUR 100 and EUR 25000 to be used towards professional services in the areas of training, coaching and strategic advice. As of 2009, design projects can also be supported.

- Training: Training programmes can support managers and employees. Examples include computer training, language training, management training and communication skills.

- Advice: Advice can be obtained on the core processes of the company, however services regarding subsidies, guidance and implementation are not eligible. Examples of support offered include market studies, development of communication plans, investment analysis, internationalisation advice and technology insights.

Small businesses can receive up to EUR 10000 to cover up to $40 \%$ of the costs of support, while medium-sized businesses can receive up to EUR 15000 to cover up to $30 \%$ of the costs. The scheme has an annual budget of EUR 50 million per year. Approximately 30000 project are supported annually.

As of 2016, the SME Wallet has been focused on the purchase of training and business advice from registered service providers. Entrepreneurs and SMEs can utilise the budget as they deem suitable, as long as the service providers are registered.

Source:https://www.vlaio.be/nl/subsidies-financiering/kmo-portefeuille

In Poland, most publicly-supported business development services are delivered at the regional level. However, in order to ensure consistency and quality of the supports provided a new database was launched in 2018 to allow the system to be more demand-driven. SMEs will have more complete information about available services and contribute to a strengthening of the system by inputting their own evaluations and ratings of the services received into the database (Box 2.2). 


\section{Box 2.2. Business Development Services Database, Poland}

The business development services developed in Poland in past decades was a supply-side driven system that was driven by the offer of business development services. Few tailored support initiatives existed and there tended to be a lack of coherence between the offer of business development services and the needs of SMEs and start-ups. Moreover, the public support system was fragmented with public support going to many different suppliers and with considerable variation in the scale and quality of business development services across the regions.

A major upgrade to the system was undertaken in 2016 involving the creation of a common national accreditation system for Business Development Institutions and Database of Development Services. The national database contains detailed information on business development services offers, presented according to a common template. This allows SME managers and entrepreneurs to search and compare all of the offers available in the different regions. The information is verified by external audits of the service providers and monitoring visits by database managers. Moreover, the SMEs and entrepreneurs using the services can evaluate the quality of the offer and assign a rating to the supplier in the database.

The main principles of database are:

- Putting the quality of services at the centre of attention and providing incentives for continuous improvement by benchmarking the business development services institutions.

- Ensuring the quality services with an external quality certification of each supplier every 3 years.

After the first year of operation, the database had more than 4 million page views, 120000 registered users, 1400 registered business development services providers (of which 550 were accredited by the Policy Agency for Enterprise Development), and more than 13000 active services offered.

The cost of development the database was approximately EUR 15 million.

For more information, please see: https://uslugirozwojowe.parp.gov.pl/

\section{Account managers to improve matching of supply and demand}

In 2015, the Wallonia region in Belgium developed the new function of "account managers" in its business development services system. These professionals work with SMEs and start-ups to help them develop roadmaps to identify their objectives and the steps they can take to achieve them. This role helps attract SMEs and start-ups into the business development services system and improves the match between the services supplied and the services needed by the enterprise. The initiative has a budget of some EUR 4.3 million for the period 2015-2023, financed through the regional government and supported by the European Regional Development Fund.

\section{New access points to business advice}

Canada, Romania and Spain have all introduced new access points for entrepreneurs to the business development services system, making it easier for SMEs and entrepreneurs to express a demand for services. In Canada, a new online platform was launched in 2018 to improve awareness about available support and how it can be accessed (Box 2.3). In Romania, these are one-stop shops, while Spain has launched "points" for entrepreneurs. 


\section{Box 2.3. Innovation Canada digital platform, Canada}

The Innovation Canada Platform was launched in January 2018, with a federal budget allocation of CDN 14 million over five years. It is an online portal that matches businesses with the public support programmes and services that best meet their needs. This includes funding opportunities, expert advice, identifying partners and suppliers.

Businesses complete information on their basic profile (e.g. province, sector, size) and objectives (e.g. hire employees, grow, improve productivity, export) and indicate the type and scale of support sought (e.g. funding, expert advice). The tool then provides links to all relevant support programmes.

In the two weeks that followed the launch, more than 20000 users completed the tool and accessed results.

Source: http://innovation.canada.cal

\section{Conclusions and policy recommendations}

Demand for business development services from SMEs and start-ups can be constrained by a number of factors. These include unwillingness of many entrepreneurs to turn to outside advice, negative perceptions of the quality and relevance of the external advice offered, and the complexity of business development services support systems. At the same time it is important not to over-invest in public business development services support, given that advice is costly and may not always generate strong impacts.

The following policy recommendations can be offered:

- Increase the quality and relevance of external advice. Build partnerships with private sector suppliers (rather than crowding them out) and accredit good-quality suppliers.

- Leverage the existing touch points of SMEs and start-ups. Seek to deliver advice through existing trusted contacts of SMEs and start-ups, such as their existing bankers and accountants, or use them to signpost firms towards relevant advice sources.

- Reduce the complexity of business development services support systems. Simplify the public business support system, for example with one-stop shops, single entry points and account managers.

- Evaluate impacts. Good quality evaluation is important to assess the impacts of these programmes against their objectives. 


\section{Targeting and segmenting the business advice market}

\section{Introduction}

There is substantial heterogeneity in SME and start-up operational characteristics and performance, implying differences in their business advice needs and the expected impacts of advice provided.

Among the key dimensions on which SMEs and start-ups vary are age and size. For example, it may be relevant to introduce different strands or intensities of business advice for new start-ups compared with established SMEs, or for sole start-up entrepreneurs as compared with larger start-ups, or micro firms as compared with medium-sized enterprises. The degree to which SMEs and start-ups are oriented to growth and innovation also varies significantly, suggesting the relevance of different strands of business development services for growers and innovators than for regular SMEs.

Other relevant distinctions include growth stage of the firm, sector, technological intensity, market, characteristics of the entrepreneur (gender, age, migration status, employment status), ambitions and motivations of the entrepreneur and enterprise, business strategy, internationalisation, and company performance (including whether survival and restructuring are issues). OECD (2020) identifies many typologies that have been developed to classify SMEs and start-ups by these types of dimensions.

One of the key areas of focus for business development services is on high-tech, radical innovator, and rapidly-growing SMEs or start-ups. However, the bulk of SMEs are "regular" established firms, which run their businesses as usual and make incremental improvements. These regular SMEs also deserve attention from business development services policies for several reasons. They have, in many cases, reached what Klofsten (1992) defines as a business platform. This means that they have an established base of customers and a working organisation, giving them a good foundation and potential for further growth. In addition, since they work with established products and markets, they ought to face lower risks of market exit than new enterprises.

This section starts by reviewing the differences in business development services needs across different types of SMEs and start-ups and giving examples of recent policy developments in targeting business development services by type of firm and entrepreneur. It then focuses on how to provide business advice to regular, established SMEs taking the case example of the Swedish business development services system.

The section argues that business development services policies should target established SMEs as well as start-ups, scale ups and radical innovators. However, the type of advice should be adapted to the firms targeted. A greater focus on basic advice for incremental management, process and market improvements is likely to be needed for regular, established SMEs, whereas start-ups, scale-ups and radical innovators are likely to require more intensive advice aimed at growth. 


\section{Firm-level distinctions for business development services}

Three key distinctions can be useful for providing different intensities or types of business development services to different types of SMEs and start-ups, namely their rate and type of innovation activity, their stage of business development and the origin of a start-up company.

\section{Innovation activity}

One of the main rationales for business advice policies for SMEs and start-ups is to stimulate innovation with the potential to generate firm-level and economy-wide productivity increases (see for example North et al., 2001; Audretsch, 2002; 2004; Audretsch et al., 2007; Stevenson and Lundström, 2007; Norrman, 2008; Braunerhjelm \& Henrekson, 2012).

However, the level and type of innovation an SME or start-up is involved in makes a difference to the type of business development services that policies should offer them. Rosenbloom and Christensen (1994) distinguish between innovation that is disruptive, sustaining or incremental. Following the matrix of Ansoff (1965), disruptive innovators (with innovative products) may need help to create new markets, while more regular SMEs (working with existing products) are likely to be seeking to increase their market penetration.

Innovation could be defined narrowly, fitting more with the concept of disruptive innovation and the focus on radical transformations in products and markets, or more broadly, allowing for incremental and sustaining innovations including technology adoption in firms (Frankelius et al., 2017). The latter is in line with the definition of innovation in the current OECD Oslo Manual as:

"the implementation of a new or significantly improved product (good or service), or process, a new marketing method, or a new organisational method, in business practises, workplace organisation or external relations."

This implies that innovation does not need to be new to the firm, but could originate with others (OECD/Eurostat, 2005; Gault, 2013).

Business development services therefore need to distinguish between support for disruptive innovators, which are aimed more at innovative start-ups and scale ups, and support for incremental and sustaining innovators, which is likely to be of principal importance for other SMEs.

Business advice to disruptive innovators is likely to require more support with market establishment. Box 3.1 gives the example of a Swedish programme for high growth firms, aimed at support for open and peer learning across SMEs experiencing growth. 


\section{Box 3.1. The SMIL Business Development Programme, Sweden}

\section{Description of the approach}

The SMIL programme has run annual programmes of events since 1986, generally administered by Linköping University, with the aim of promoting open learning among growing businesses. Each annual edition normally consists of three one-day workshops, distributed over one year. Additional informal meetings among participants have been encouraged between the workshops, without a programme leader present. As the participants have been more or less experienced in different areas, they have often worked as informal mentors or sparring partners to each other and the relationships built during the programmes have often become long lasting.

More than 20 annual editions have been run, with a total of some 500 participating individuals representing some 200 firms. Some of the firms have participated in the programme several times.

\section{Strengths and challenges}

The main strengths of the programme are that it originated from a regional network of businesses that asked to participate, and that it has been run several times, enabling learning and networks to emerge among the firms that have participated. An additional strength is its flexibility, with each edition tailored to the interests and needs of its participants.

Initially a challenge was getting the right number of participants to facilitate mutual learning and networking. Some 20 SMEs participated in the first edition of the programme. However, this group was judged to be too large. Hence, the number of participants in the subsequent editions was limited to 9 firms.

Another challenge is that at least one experienced entrepreneur is needed as a programme leader; the programme could not be run by policy actors alone.

\section{Key success factors}

From an interview study with participants, Klofsten and Jones-Evans (2013) identified eight key success factors of the programme. These are:

1. Engaged programme leadership - an engaged leader is very important to create and carry the culture of the programme.

2. Openness between participating entrepreneurs - $a$ friendly and constructive climate among the participants implies that problems are taken seriously and that there are joint efforts towards solving them.

3. Willingness to share ideas and experiences - this is something that has evolved and become the essence of the programme. Since some firms have participated more than once, this culture of openness has been inherited through successive editions of the programme.

4. High level of company engagement - despite the fact that some participants have found themselves being almost competitors they have managed to engage to solve common problems.

5. Tolerance of all opinions when discussing problems - this culture has made the participants feel comfortable both to raise problems and suggest solutions.

6. Informality and programme flexibility - because the programme management has been very experienced, it has managed to tailor the programme to the participants. 
7. Needs-oriented process - a lot of growth problems have been common to almost all the firms and hence needs have often been easy to identify and the issues chosen have engaged all the participants.

8. Continuous learning by participating companies - bringing together people with common problems builds the foundation for lasting networks.

For regular SMEs, the focus of efforts is likely to be on increasing competence and knowledge in the areas of adopting existing best practice process technologies (e.g. in digitalisation or automation), improving existing business models, or expanding markets and customers. The advice offered helps SMEs to respond to ongoing trends such as the digital transformation, rapid technological change and demographic ageing which change markets, competition and technologies, whether or not the firms are new or innovative or experiencing growth. The ability to support firms to address these challenges is crucial.

Frankelius (2009) and Frankelius \& Norrman (2013) suggest that innovation in an SME could emerge in many areas, for example new solutions, products, services, processes, organisations or business models, methods, concepts, designs, names or experiences. Hence a broad view of what could be supported in terms of innovation in businesses is beneficial. This should include technology adoption, and not only innovations that could be patented.

\section{Business lifecycle stage}

Another important distinction for business advice policies is between nascent/new enterprises and entrepreneurs on the one hand and existing SMEs on the other (Lundström and Stevenson, 2002, 2005; Stevenson and Lundström, 2007).

Following Stevenson and Jarillo (1990), entrepreneurship can be defined as:

"a process by which individuals - either on their own or inside organizations - pursue opportunities without regard to the resources they currently control" (p.23).

This aligns with the conception of Schumpeter (1934), which considered an entrepreneur as someone putting together new combinations (see Norrman, 2008). Business advice for nascent/new enterprises may therefore need to focus particularly on handling the risk taking activity that is inherent in the entrepreneurial process (McKelvey \& Zaring, 2016). This again may differ from the types of increased knowledge and competence required to help established SMEs to improve and stay competitive (Bager-Sjögren et al., 2003).

At the same time, according to both research and practice (Philipsson, 2018; Brown et al. 2017; North and Smallbone, 2012), growth potential can be found both in established SMEs and in new start-ups. For example, North and Smallbone (2012) show that the age of the firm is not a crucial factor determining growth and that older SMEs can also achieve growth. Brown et al. (2017) state, in their study of high growth firms that "recent evidence further indicates that the majority of HGFs are in fact older and larger than previously believed" (p. 420). This suggests the relevance of developing targeted support for both startups and older firms in the business development services system.

\section{Start-up origin}

The type of origin of the firms is another dimension of the enterprise base that needs to be taken into account when considering how to target and segment support for business development services. Bergek and Norrman (2015) compared academic spin outs with firms that spin out from industry and found that firms that originated in academic research have a greater need for business skills than industry spinoffs. 


\section{Social and environmental impact}

The expected social benefits of investments in business development services can be expected to vary across different types of SMEs and start-ups. For example, business development services that support new job creation in areas with low or negative employment growth or that create new jobs for previously unemployed or hard-to-employ persons could be considered particularly valuable to society. Similarly, growth stimulated in SMEs and start-ups may be relatively more valuable to society if for example they grow market share in foreign rather than domestic markets, or if they help solve difficult infrastructural, social or environmental challenges; such as helping address environmental sustainability goals.

It may therefore be worthwhile considering some targeting of additional or dedicated business development services on green tech ventures, social enterprises, firms established by people from under-represented groups in entrepreneurship, export-seeking ventures etc. The recent trend towards impact investment suggests the feasibility and desirability of making investments with social and environmental returns as well as economic returns.

Box 3.1 explores a business advice programme that targets SME and entrepreneurship development in rural areas as an example of area-based targeting of support.

\section{Box 3.2. Rural Growth Pilots, Denmark}

The Rural Growth Pilot (RGP) is supported by the (public) Danish Innovation Fund (Innovationsfonden) with the aim of supporting SMEs in rural areas by providing them with complementary skills sets in the form of support for hiring graduates (with at least a university master's degree).

The concept of the programme was based on prior research that had shown that those SMEs taking on a graduate had better performance than those that did not - increased likelihood of firm survival $(2.2 \%)$, increased employee growth (4.5\%) and increased value added (38\%) over a three-year period. The impact was assumed to come about through the infusion of new and complementary skills sets into the SMEs, and fusing the academic skills of the graduate with the practical skills and experiences of the SME owners and employees. Notably, the recruitment of the graduates was expected to stimulate a greater internal drive for development and growth.

The RGP programme applies this logic to SMEs in rural areas in Denmark, where SME growth and innovation levels are lower than non-rural areas and where there is a greater need for creating graduate employment.

The programme provides financial support to rural businesses worth DKK 150000 (EUR 20 000) per year for a maximum of two years to hire a graduate. The SME must make a competitive application in which it provides an idea for a new product, market, production method or service innovation as well as a description of the role that the graduate will play in its development. Evaluations of similar projects suggest that the process of developing the application is manageable for the SMEs, and that there is a reasonably high success rate from the applications.

It is a requirement that the graduate hired should have a different skillset from the current employees. To identify relevant graduates, the SMEs can tap into a network campaign designed to create a pool of graduates interested in working with SMEs.

An additional element of the support involves linking the firms into advisory services from the regional business support centre (væksthuse) to help them deliver their projects successfully.

A total of DKK 40 million (EUR 5.3 million) has been allocated to the project over a four-year period. 


\section{Motivations}

SMEs and start-ups also vary in their firm's willingness to participate in development programmes and willingness to learn (Wolff et al., 2015). Drawing on studies like Klofsten and Norrman (2013) and Stevenson and Jarillo (1990), it is clear that entrepreneurship is about attitudes and strong driving forces. If the willingness to adopt new ideas and learn is missing, it is probably not effective to support the company (North and Smallbone, 2012). It can therefore be effective to target more costly programmes to those SMEs and start-ups expressing a need to improve their businesses and to firms ready to pay some fees to follow a programme (Klofsten and Jones-Evans, 2013).

\section{Recent policy initiatives for targeting and segmenting business advisory services}

\section{Introducing new targeted programmes}

The most common approach that governments have adopted for increasing the targeting and segmentation of public business development services during the last five years has been the introduction of new targeted programmes that aim to support a specific segment of the business population. Examples are set out below:

- $\quad$ Canada. The federal government has strengthened business development services for womenoperated SMEs in Canada over the past decade guided by the introduction of a new Women's Entrepreneurship Strategy announced in 2018.

- $\quad$ Czech Republic. The government's Czechlnvest agency launched a new package of consulting services in 2016 with four activities targeted at high-growth firms and firms seeking to establish operations in another country. CzechStarter provides mentoring and counselling for up to seven months. CzechAccelerator offers premises for high-growth potential firms in the United States (Silicon Valley, New York), Singapore or London, along with mentoring, consulting, and intellectual property protection support. CzechDemo and CzechMatch support businesses that are looking for foreign investors or to launch operations in foreign countries.

- Spain. The Business Growth Programme was launched in 2016. It provides tailored advisory services in the areas of digitalisation, innovation, finance, marketing and marketing, operations and human resources. In addition, advisers can help identify financing options, as well as services available from the Bank of Santander.

- $\quad$ Sweden. Digilyft was launched in 2017 to enhance digitalisation among existing SMEs. The current activities focus on awareness raising, but mentoring will be included in future phases of the programme.

\section{Organising services according to business needs}

Rather than introducing new programmes for certain business populations, some governments have preferred to introduce a more strongly targeted and segmented approach across existing business development services and support programmes.

- Flanders, Belgium. The Agency for Innovation and Entrepreneurship (VLAIO) is a governmental organisation of the Flemish government (Belgium) created in 2016 by the merger of the innovation agency and the entrepreneurship agency. The new agency has developed support services for nine segments of the business population according to their business life-cycle stage and maturity of innovation. 
- Wallonia, Belgium. The Wallonia regional government launched a new business development services voucher system in 2017 - the "Chèques-Entreprises" platform. This enables SMEs and entrepreneurs to request vouchers co-financed by the regional government in order to benefit from training, business counselling and coaching support from accredited service providers. Services are organised according to business needs (e.g. internationalisation, digital, innovation, operational excellence, intellectual property) and stage of development (in the creation phase, in growth or at the stage of the transmission).

- Mexico. The Productos y Beneficios programme was launched in Mexico in 2013. It is a selection of tools offered by both public and private sector providers within the Red de Apoyo al Emprendedor (Entrepreneur Support Network). Support offers are organised by type of product or service, and location of support offer.

\section{A step-wise support approach}

Almi Företagspartner is one of the main players in business development services delivery in Sweden. It is set up as a state-owned national company group with 16 regional subsidiaries and activities financed by national and regional government and European Union funds. It offers business counselling and advice coupled with financing to growth-oriented firms at different stages of development. Although its aim is to support innovative firms with growth aspirations, the agency has a broad view of what counts as innovation and supports both radical and incremental innovation. Over time, it has seen a shift from technologyoriented support to service innovation, including the promotion of new business models.

The agency offers finance and business advice to regular SMEs as well as high growth and innovation performers, recognising that enterprise growth can happen at different points in time and for various reasons and that support may be required to match the challenge faced. For example, an SME could be forced to change because of a declining market or could experience a generational change, where founders retire and a new generation takes over, and business advice can be provided accordingly.

This calls for stepwise support, which evolves with the company's needs, instead of throwing large sums at single time or on a few occasions. Almi Företagspartner therefore designs its support activities to provide small sums to a large number of companies and requires the achievement of milestones in company progression prior to allocating additional financial support to individual companies.

The business advisors provide generic counselling, coupled in some areas with specialist advice. For areas where the business advisors lack competence, they co-operate with outside actors and consultants. In Östergötland, for example, a long tradition of co-operation exists between support actors. This tradition goes back previously to an organisation called Growlink and is taken forward today through the East Sweden Business Region (ESBR), which incorporates a larger geographical area than Growlink.

\section{Conclusions and policy recommendations}

There is substantial heterogeneity in business advice needs and impacts across different types of SMEs and start-ups. Among the key distinctions are firm size, age, innovation and growth activity and social and environmental impact. This calls for adaptation and segmentation in the business advice system. The following key policy recommendations can be offered:

- Support both low-productivity and more ambitious firms. Support for regular SMEs should not be neglected in favour of more innovative and growth-oriented start-ups and scale-ups. Even if they are not focused on radical innovation and growth, SMEs have a constant need for new competence development and adoption of new and innovative business models and production processes to stay successfully in business. For example, for a low-productivity, established SME to remain 
competitive it might need to increase its degree of digitalisation, turn towards a more serviceoriented business model or even try to come up with a brand-new business model.

- Provide more intensive support where there can be more impact. Whereas support for regular SMEs may be fairly basic and generic and focused on introducing existing best management practices, support for innovative start-ups and scale-ups may need to be more intensive and tailored, and linked to opportunities for access to financing. Levels of public investment in business development services should take into account the growth impacts that can be expected from the support provided, implying greater cost tolerance for SMEs and start-ups with greater growth potential. It should also take account of how different types of SMEs and start-ups may deliver additional social benefits, for example by employing hard-to-reach social groups or supporting green entrepreneurship, suggesting greater tolerance of public costs for these high-benefit firms. In addition, the offer of more costly business advice services should be targeted on SMEs and start-ups that express an openness to receive advice and act on it and that are willing to participate in meeting some of the costs.

- Install a two-tier business advice model. A two-tier model can distinguish between these two broad categories of user firms. The first tier delivers generic advice to large numbers of SMEs and startups. Strong branding and visibility and one-stop entry points can facilitate access to this structure, but without strong marketing and recruitment efforts for individual firms. The second tier involves a more intensive, holistic and tailored set of services targeted at SMEs and start-ups with growth motivations and knowledge-absorption capacities, supported by more intensive but more targeted marketing and company recruitment efforts.

- Differentiate advice between new and established firms. Advice for nascent entrepreneurs and start-ups should be differentiated from advice for established SMEs, with greater emphasis in startup advice on risk taking and establishing new markets.

- Introduce targeted support. Methods that can be introduced to target and segment business development services support across different types of SMEs and start-ups include introducing new targeted programmes, such as for women entrepreneurs or growth-oriented entrepreneurs, and organising the services of business development services institutions by SME and start-up type or type of service offered.

- Use a step-wise approach. It can be useful to organise a step-wise approach to delivery of business advice, potentiallly linked to access to finance support. This could involve offering SMEs and startups access to additional more targeted advice on the condition that they pass certain business development or growth milestones.

- Include support for peer learning. Peer learning approaches should be considered as a method of offering advice and mentoring to groups of like-minded firms. Creation of a trustful and open climate among participants is highly important for this type of programme. 


\section{Digital business diagnostic tools}

\section{Introduction}

The digital transformation is improving the availability of information, knowledge and data, with important impacts both on how government services are provided and on the business models of SMEs and startups (OECD, 2017). One of the opportunities this presents, is for governments to reach out to more SMEs and start-ups with business advice using online business diagnosis tools. Such tools can make benchmarking and guidance available to any interested SME or start-up, "just one click away", and regardless of location. Many more SMEs and start-ups can potentially be reached at reasonable cost than is possible with traditional face-to-face or telephone-based business diagnostic services, whilst building a new bridge to interested firms into the business support system. At the same time, advice and guidance provided will be relatively generic and limited compared with in-person support.

This section considers the role of policy in supporting digital business diagnostic tools for SMEs and startups. It examines the policy issues, classifies different types of tools, discusses recent policy trends, and gives a number of examples of publicly-supported tools that have been developed internationally. Finally, the section offers conclusions and policy recommendations on introducing digital business diagnostic tools.

\section{Policy issues in the development of digital diagnostic tools}

\section{The benefits of digital business diagnostic tools}

The key advantages of digital business diagnostic tools for supplying business development services to SMEs and start-ups are that they are easy to use for the entrepreneur and have low marginal costs of delivery for the provider, although there are significant costs to set the tools up in the first place.

Digital business diagnostic tools are well placed to "nudge" firms towards better management practices. They offer a means for managers and entrepreneurs to assess the strengths and weaknesses of their SME or start-up against good practices or against peer firms, potentially exposing areas for improvement that the SME managers or entrepreneurs were not previously fully aware of. They can provide follow up learning opportunities through guidance materials hosted on the internet tool site on how to address weaknesses and exploit areas for improvement. They can also help SMEs and start-ups to anticipate emerging challenges in technologies, competition and markets and react quickly to changing circumstances according to their strategy, mission and priorities. By arousing interest and providing linkages to more intensive forms of public and private business advice and support, digital diagnostic tools can also boost demand for business development services.

Some of the main benefits that SMEs and start-ups can derive from using online business diagnostic tools are as follows:

- Carrying out a meaningful diagnostic against good-practice business management standards. 
- Obtaining data comparisons and benchmarks with other firms, helping to understand relevant gaps and set related improvement targets.

- Identifying well-defined and prioritised improvement actions for the business.

- Offering learning opportunities to managers and entrepreneurs on how to implement changes.

- Generating alignment among the key managers within the SME or start-up on the development priorities and initiatives to be pursued.

Some limits of digital business diagnostic tools also have to be recognised. The guidance is relatively generic and basic, the diagnostic may raise questions for the user that are difficult to answer online, and the tools may lack a mechanism to secure consensus or action on the part of the different managers and stakeholders of the business.

\section{The role of public policy}

In principle, digital business diagnostic tools, like other forms of business advice, could be supplied privately. However public sector involvement can be important in overcoming a number of barriers that can constrain the use of these tools by SME managers and entrepreneurs.

The main barriers are as follows:

- Lack of knowledge about the availability of online business diagnostic tools, which are best suited to their business from the range of tools available, and where to find them.

- Concerns about the reliability of the data being used for benchmarking purposes and concerns about privacy and confidentiality of data that users are asked to enter into the tools to enable benchmarking.

- Lack of motivation or resources within the SME or start-up to use the diagnostic as a starting point for a continuous improvement journey, which would involve the definition and implementation of improvement actions and repetition of the diagnostic on a regular basis.

The main roles of public policies in this area can therefore be seen as promoting these tools to SMEs and entrepreneurs, providing trustworthy and relevant data frameworks, and supporting the translation of diagnostics into practical implementation of improvement actions by firms.

More specifically, public policies may support digital business diagnostic tools by:

\section{Awareness and accessibility of tools}

- Diffusing information on those available tools that are most appropriate for different kinds of firms.

- Ensuring that tools are available that are suited to conditions in the countries concerned, including making national language versions available.

- Supporting SMEs and start-ups to use the tools by making technical helpdesk services available, providing training and support to staff in public agencies to support firms with the tools, or incentivising third-party service providers (such as higher education institutions) to help SMEs to use the tools (e.g. by offering vouchers to SMEs and start-ups for support to use the tools).

\section{Trustworthy and relevant data frameworks}

- Developing appropriate and independent conceptual frameworks to underlie the tools, setting out which types of practices are important and which types of data and guidance should be applied.

- Inputting reliable and meaningful data from public sector sources (tax and social security records, business census data etc.) to support well-contextualised comparisons and benchmarking.

- Using a public purpose commitment to reassure user firms about the usage of the data they input. 


\section{Translating diagnostics into action}

- Integrating independent information into the tools on follow-on information and support from public and private sources.

- Offering subsidised advice, training or finance to SMEs and start-ups requiring support for implementation of actions following a diagnostic. For example, public financial support, such as vouchers, could be provided conditional on SMEs and start-ups providing evidence of changes made for instance 6-12 months after the diagnostic.

\section{Examples of digital business diagnostic tools}

Digital business diagnostic tools can be classified into two main types:

- Generic tools that support SMEs to identify their overall strengths and weaknesses and areas for improvement.

- Domain-specific tools, for example focused on innovation, internationalisation or digitalisation.

An SME or start-up could choose one of these tools, or combine them together, depending upon the fit of the tool to the specific business development strategy, goals and priorities of the firm.

\section{Generic tools}

\section{Business Productivity Benchmarking Tool, Business Development Bank, Canada}

The Business Development Bank Canada (BDC) is a public financial institution providing a range of finance and advisory services to SMEs and start-ups through a network of 118 business centres across Canada. Its Business Productivity Benchmarking Tool enables SMEs to compare their productivity performance against peers in the same industry, so as to understand where they stand and how they can improve. The tool is based on the following five indicators: 1) overall level of productivity; 2) revenue per employee; 3 ) profit per employee; 4) labour productivity; and 5) capital productivity. Users input the data for their own firms, which is benchmarked with peers using data provided by the Canadian Center for Data Development and Economic Research (CDER) of Statistics $\mathrm{Canada}^{7}$ and corporate federal income tax returns. Each user firm receives a printable benchmarking report together with recommendations and information on best practices.

\section{SizeUp, Small Business Administration, USA}

The United States Small Business Administration (SBA) provides a large variety of business support and advice through a network of 1800 offices distributed across the USA. SizeUp ${ }^{8}$ is an online assessment tool that processes millions of geographically-indexed data sets to enable SMEs and start-ups to map their main customers, find the best places to locate their products/services or to advertise them in a more efficient way, and set appropriate targets. The tool has three main components:

- Benchmarking the business. The tool benchmarks the user firm's performance with its main competitors in the same region and field of activity. This is used to provide guidance on wage levels, potential cost efficiencies, expected sales and numbers of customers that the user firm

\footnotetext{
7 Canadian Center for Data Development and Economic Research (CDER) of Statistics Canada. See more: http://www.statcan.gc.ca/eng/cder/index
}

${ }^{8}$ SizeUp. See more: https://www.sba.gov/tools/sizeup 
should be able to achieve, based on relevant data and information collected from a large number of similar firms.

- Mapping the competition. The tool identifies the potential main competitors in the region in which the SME or start-up operates. This provides guidance on where to locate its operations, taking into account competition and customers.

- Determining when and where to advertise. This component of the tool provides guidance on where to market and advertise a specific service or product taking into account the goals and resources of each user firm, including the best places and the best times to advertise from a wide range of possible options both online and offline.

\section{Enterprise Development Programme, Enterprise Estonia, Estonia}

Enterprise, Estonia's Enterprise Development Programme, with a total budget of EUR 73 million, aims to develop at least 20 brand new and globally-unique products or services by 2024 by supporting ambitious SMEs and start-ups in preparing and implementing a development plan. As a first stage of participation, SMEs and start-ups can use an online diagnostic tool to establish their ambition and readiness for change. The diagnostic is made up of 60 questions covering: 1) starting point and ambition; 2) competitive factors; 3) customers and markets; 4) sales and marketing; 5) products and prices; 6) distribution channels; 7) product development, production and logistics; 8) resources and know-how. This leads to a visually presented competitiveness profile for the user firms, pointing to potential areas for improvement (Figure 4.1).

\section{Figure 4.1. Competitiveness profile obtained from EAS online assessment tool}

Example of output of the tool for a hypothetical firm

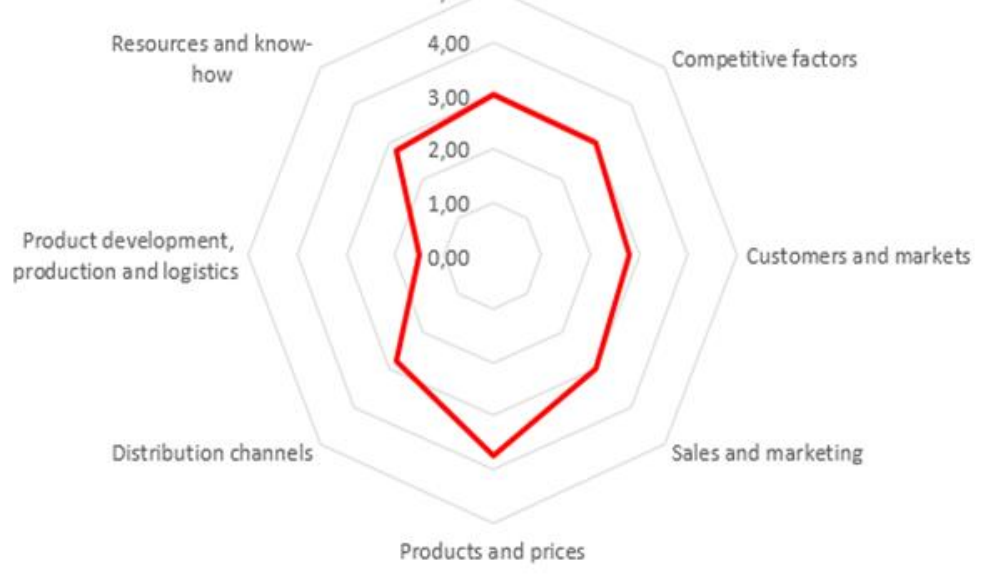

Source: Enterprise Estonia. Author's own self-evaluation questionnaire based on Enterprise Estonia online tool. See https://www.eas.ee/teenus/enterprise-development-programme-2-2/?lang=en\#articleblock-1stageenterprisesambitionandreadinessforchange.

\section{Business Excellence and Business Toolkits, Enterprise Singapore, Singapore}

Business Excellence is a simple online digital tool that enables SMEs and start-ups to assess their organisational performance according to an internationally-benchmarked framework covering the following seven areas: 1) leadership; 2) customers; 3) strategy; 4) people; 5) processes; 6) knowledge; 7) results. Enterprise Singapore also independently certifies the achievements and commitment of SMEs and startups to sustainable performance improvement by awarding Business Excellence certifications in the form 
of a Quality Class award, Quality Class Star, or Excellence award, overall or in specific operational areas (Service, People or Innovation). ${ }^{9}$

Enterprise Singapore also provides the following online Business Toolkits:

- SME Financial Modelling. This assesses the financial management of the SME, identifying major areas for improvement and resources that can be used to improve its financial resilience.

- HR Self Diagnosis. ${ }^{10}$ This explores an SME's stage of development in people, talent and human capital. It generates a self-assessment profile based on the user's answers to a comprehensive set of questions on human resources management and steers the user to suggested approaches and reading on further development. It was developed by Enterprise Singapore in partnership with the National Trades Union Congress (NTUC) and the Chartered Institute of Personnel and Development (CIPD).

- Market Assessment. ${ }^{11}$ This tool helps SMEs to assess their market development opportunities. It presents a framework that allows users to evaluate the potential and attractiveness of new markets, both at the local and international levels, for business expansion purposes.

\section{Chambers of Commerce, France}

The French Permanent Assembly of Chambers of Commerce and Industry - a national public body - has developed an IT platform on behalf of the network of local public chambers of commerce, which provide extensive business development services to SMEs and start-ups in their localities. The tool enables user SMEs and start-ups to undertake diagnostic assessments, automatically drawing up a summary report on the situation of the firm based on the user's answers to a questionnaire. The diagnostic helps SMEs and start-ups to revise their priorities and identify areas requiring further support from the local Chambers. The user can undertake the self-assessment in one or more of the following domains: 1) administrative and financial management; 2) sales and marketing; 3) production, purchasing and supplies; 4) human resources management; and 5) the future of the business.

The tool is in use in more than half of the 104 Chambers of Commerce and Industry in France, and aims to assess some 10000 SMEs every year (European Commission, 2010). The successful outreach of the tool is considered to derive from its ease of use, the fact that it can be adapted to the requirements of very small businesses and its "bottom-up" approach based on the needs and enquiries of the firms.

\section{FutureSME Capability Diagnostic Model, European Union}

The underlying models, IT platforms and diagnostic tools of the futureSME Capability Diagnostic Model were developed with support from the European Commission and involved a consortium of 26 partners, including 13 manufacturing SMEs, research and development organisations and SME support agencies from eight countries (Czech Republic, Ireland, Italy, Poland, Turkey, the Slovak Republic, Sweden and the United Kingdom). ${ }^{12}$

To conduct the online diagnostic, the user inputs information about the company and responds to a survey covering indicators and approaches adopted in the following areas: 1) strategy; 2) operating model; 3) process management; 4) performance management; 5) leadership; 6) governance; 7) agility; and 8) innovation. The tool automatically generates an output report highlighting the key priorities the firm needs to address in order to improve its competitiveness and performance. It uses a Visual Management System to illustrate how the firm compares to other SMEs. This makes use of results obtained for a sample

\footnotetext{
${ }^{9}$ See: https://spring.enterprisesg.gov.sg/Building-Trust/Business-Excellence/Pages/business-excellence-overview.aspx

${ }^{10}$ HR Self-Diagnostic Tool. See more: $\underline{\text { https://hrportal.sg/self-assessment-page/ }}$

${ }^{11}$ Market Assessment: See more: https://web.smu.edu.sg/spring/

12 See http://www.futuresme.eu
} 
of SMEs. Figure 4.2 shows the type of visual used to display results. In addition, the platform includes case studies, videos and practical advice in responding to the diagnostic.

Figure 4.2. Example of future SME capability diagnostic results for a hypothetical firm

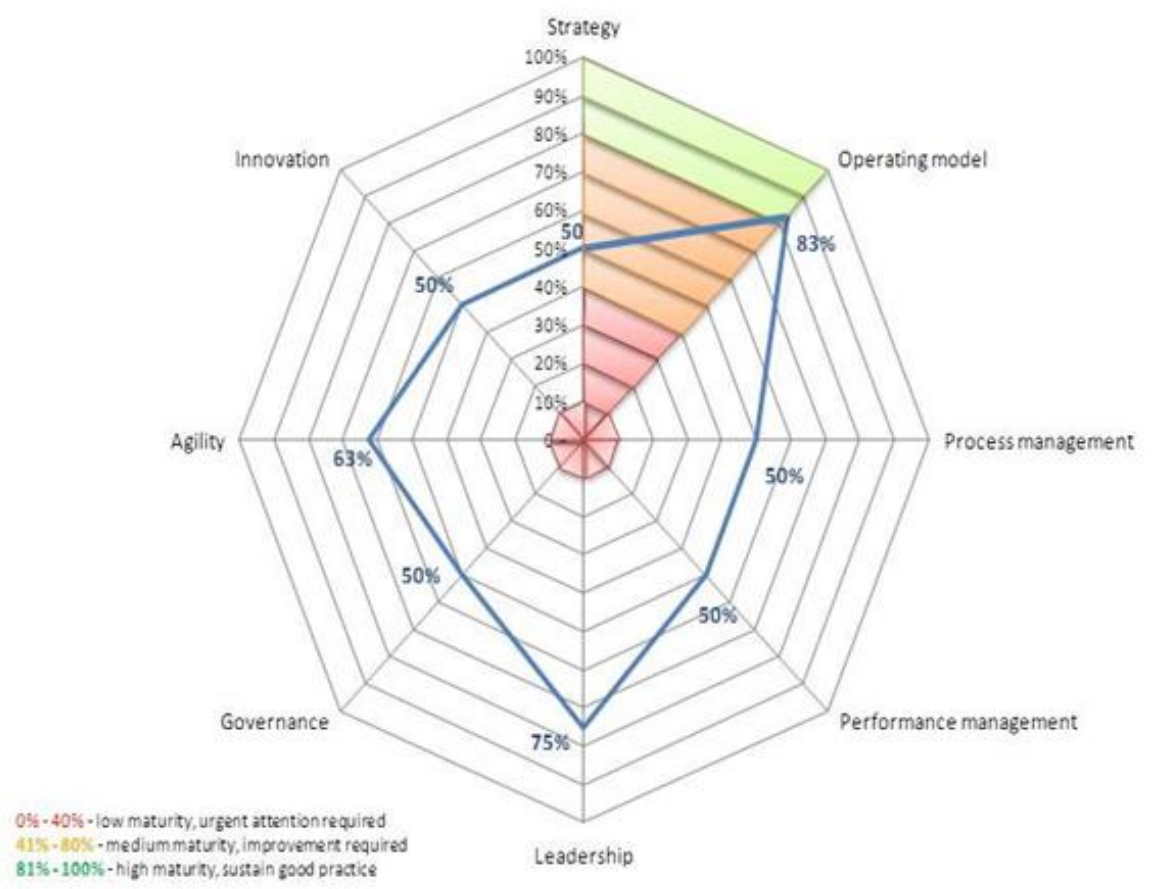

Source: Author's elaboration of a hypothetical firm results from use of the futureSME tool; see http://www.futuresme.eu/diagnostic

As an example of the types of benefits that users can achieve, the tool's website gives testimony from the Turkish SME, Deka, which achieved the following benefits:

- it helped employees from different departments to communicate on a new basis and to understand the weak links in the business;

- management had the opportunity to evaluate the company with respect to its strategic, operational, managerial and adaptive capabilities;

- the management team was able to align improvement projects with the main goals of the business;

- an innovation project - a production and sales feasibility check - was launched, which resulted in an $80 \%$ decrease in the usual product appraisal time thus enhancing competitiveness in the market.

\section{Diagnosis 1. Tell us about you, Mexico}

The Mexican government has developed this online diagnostic tool for SMEs and entrepreneurs (Diagnóstico 1. Cuéntanos de ti) as part of its Entrepreneur Support Network (Red de Apoyo al Emprendedor) platform. The aim of the tool is to identify potential government support programmes that could be relevant for the business based on a rapid self-assessment of the business. 
Holistic Industry Productivity Scorecard (HIPS) Calculator, Singapore Business Federation, Singapore

The Holistic Industry Productivity Scorecard (HIPS) Calculator helps SMEs to evaluate the effective and efficient use of resources. ${ }^{13}$ Through 10 key indicators, user firms are able to understand their respective performance percentiles compared to industry-specific benchmarks. It aims to support SME managers and entrepreneurs to understand and quantify, in a quick but well-defined way, what productivity is all about, how it can be properly measured and what action may be needed to increase productivity.

\section{Domain-specific tools}

\section{Digitalisation tools}

\section{Improve Academy, Germany}

The Improve Academy has developed the IMP3rove Approach digital diagnostic tool for assessing and benchmarking the digital innovation management capabilities and performance of firms against the average scores of direct or indirect competitors. ${ }^{14}$ The user companies must address a set of predefined questions, with four types of assessment available:

i. A basic assessment to identify the strengths and weaknesses of the company's digital innovation.

ii. An assessment that uncovers the drivers and challenges of digital innovation management and performance.

iii. An assessment to demonstrate the degree to which a company manages innovation in a sustainable manner.

iv. A structured assessment of the company's performance in digital innovation based on user responses to questions along five dimensions (see Table 4.1). An overall Digital Innovation Quotient value is provided from the results and can be calculated for companies of all sizes, ages and industries.

\footnotetext{
13 "A Guide to Integrated Management of Productivity Activities (IMPACT)", SPRING Singapore

${ }^{14}$ IMP$^{3}$ rove - European Innovation Management Academy. See https://www.improve-innovation.eu
} 
Table 4.1. IMP³rove Digital Innovation Quotient Components

\begin{tabular}{|c|c|c|c|c|}
\hline $\begin{array}{l}\text { Digital innovation } \\
\text { strategy }\end{array}$ & Digital business model & Digital processes & $\begin{array}{l}\text { Digital ecosystem and } \\
\text { culture }\end{array}$ & $\begin{array}{l}\text { Enablers for digital } \\
\text { innovation }\end{array}$ \\
\hline $\begin{array}{l}\text { General objectives for } \\
\text { digital innovation }\end{array}$ & $\begin{array}{r}\text { Characteristics of } \\
\text { customer interaction }\end{array}$ & $\begin{array}{r}\text { Development of digital } \\
\text { innovation: } \\
\text { - development processes } \\
\text { - time to market }\end{array}$ & $\begin{array}{r}\text { Digital ecosystem: } \\
\text { - organisation of digital } \\
\text { innovation } \\
\text { - governance of digital } \\
\text { innovation } \\
\text { - contribution to digital } \\
\text { innovation } \\
\text { - business partner } \\
\text { connection } \\
\text { - development of digital } \\
\text { partner ecosystem }\end{array}$ & $\begin{array}{r}\text { Development of digital } \\
\text { capabilities }\end{array}$ \\
\hline $\begin{array}{l}\text { Functional scope for digital } \\
\text { innovation }\end{array}$ & $\begin{array}{r}\text { Role of data: } \\
\text { - data capturing } \\
\text { - data analytics }\end{array}$ & $\begin{array}{r}\text { Process automation for } \\
\text { delivery of digital } \\
\text { innovation }\end{array}$ & $\begin{array}{r}\text { Digital culture: } \\
\text { - general digital } \\
\text { capabilities } \\
\text { - incentives for digital } \\
\text { innovation }\end{array}$ & $\begin{array}{r}\text { Financial resources for } \\
\text { digital innovation }\end{array}$ \\
\hline $\begin{array}{l}\text { Digital innovation trends } \\
\text { affecting the firm }\end{array}$ & $\begin{array}{r}\text { Economic indicators: } \\
\text { - revenue } \\
\text { - growth in revenue } \\
\text { - operational profit } \\
\text { - growth in employees }\end{array}$ & $\begin{array}{r}\text { Digital marketing: } \\
\text { - utilisation and business } \\
\text { impact of digital marketing } \\
\text { - size of social media } \\
\text { network }\end{array}$ & & $\begin{array}{r}\text { IT risk and compliance : } \\
\text { - specialised expertise in } \\
\text { IT, risk management, legal } \\
\text { and tax affairs } \\
\text { - IT process efficiency } \\
\text { - IT resilience } \\
\text { - cyber security } \\
\text { awareness and measures }\end{array}$ \\
\hline $\begin{array}{l}\text { Characteristics of the } \\
\text { digital innovation strategy }\end{array}$ & $\begin{array}{r}\text { Digital economic } \\
\text { indicators: } \\
\text { - digital revenue } \\
\text { - digital innovation }\end{array}$ & $\begin{array}{l}\text { Revenue generated via } \\
\text { digital sales channels }\end{array}$ & & $\begin{array}{r}\text { Impact measurement of } \\
\text { digital innovation }\end{array}$ \\
\hline \multicolumn{5}{|l|}{$\begin{array}{l}\text { Revenue growth } \\
\text { expectation }\end{array}$} \\
\hline 5 questions & 10 questions & 6 questions & 7 questions & 7 questions \\
\hline
\end{tabular}

Source: Improve Academy; see https://www.improve-innovation.eu/our-services/assessments/digital-innovation-quotient/

On completion of the online assessment, the tool automatically generates a customised report comparing the assessed SME's digital innovation management capabilities and performance with the average results available for around 5000 direct or indirect competitors.

\section{Bpifrance Digitalisation Metric, France}

Bpifrance is a public development agency and bank focused on promoting SME and entrepreneurship development in France through business advice and finance programmes. It has approximately 2500 employees and a network of almost 50 regional offices, and supports over 7000 SMEs and start-ups every year. Its Digitalisation Metric (Digitalomètre) allows SMEs to measure their level of digital maturity, identify their progression phases and discover Bpifrance support offers adapted to their needs. Bpifrance also provides comprehensive, free online e-learning content to SMEs and start-ups linked to the tool.

\section{Quick Scan Digital Maturity and Quick Scan Industry 4.0 Online, Wallonia, Belgium}

The Quick Scan Digital Maturity (Quick Scan Maturité Numérique) tool was launched in 2016. It is a short tool (60 questions that can be completed in 25 minutes) about the company's level of development in: infrastructure, processes, human resources, and customer relationships. It can be completed freely online 
or with a business adviser. Four different questionnaires are available: generic, retail, construction and einvoicing.

This is complemented by the Quick Scan Industry 4.0 Online (Quick Scan Industrie 4.0 Online) tool, which was launched in 2017. This tool is aimed at raising awareness of the challenges and opportunities of Industry 4.0, and assessing the degree of digital maturity of a company.

\section{Advanced Digital Self-Diagnostic Tool, Spain}

The Advanced Digital Self-diagnostic Tool (Herramienta de Autodiagnóstico Digital Avanzada) ${ }^{15}$ was launched in 2017 by the General Secretariat for Industry and SME, under the Ministry of Economy, Industry and Competitiveness, as part of the public-private initiative Industry Connectiveness 4.0 (Industria Conectada 4.0), which seeks to strengthen the digital transformation in Spain. It is a free online tool that allows companies to assess their level of readiness and maturity (including processes, products and business models) to begin a digital transformation towards Industry 4.0.

The online tool allows free access to a questionnaire about the company's state of digital adoption. Based on this information, the tool provides a summary of results including an evaluation of the level of maturity of the company and a benchmarking with other companies in the same sector according to their size and location. These results will support companies in planning the development and implementation of specific actions and projects to increase their competitiveness and efficiency in the current and future market.

The government also plans to develop an Industry Digital Maturity Indicator (IMDI) with the information collected to measure the degree of progress of each sector.

\section{Innovation tools}

\section{COTEC Portugal}

COTEC Portugal is a non-profit network led by private companies and supported by national government in Portugal with the aim of promoting innovation in businesses. It is linked into an international COTEC network, which also includes national networks in Italy and Spain. As one of its innovation support activities, COTEC Portugal has developed an online Innovation Scoring diagnostic tool. The tool aims to stimulate SMEs to undertake a self-assessment of their innovation performance across different dimensions influencing innovation outcomes, and to identify areas for potential improvement, hence developing their innovation activities in a more systematic, efficient and effective way.

The tool includes questions covering 14 dimensions across five pillars, as set out in Table 4.2. The SMEs undertake an assessment based on 30 innovation-related questions overall. The IT platform then automatically generates a feedback report, including an algorithm which is applied to the data provided. This allows for comparisons to be made between average values and top performers amongst the SMEs that have used the tool.

\footnotetext{
${ }^{15}$ https://hada.industriaconectada40.gob.es/hada/register
} 
Table 4.2. Dimensions assessed in the COTEC Portugal Innovation Scoring tool

\begin{tabular}{|c|c|c|c|c|}
\hline A. Strategy & B. Organisation & C. $R+D+I$ processes & D. Enablers & E. Impact \\
\hline A1. Contextual analysis & $\begin{array}{l}\text { B1. Structures and } \\
\text { governance }\end{array}$ & $\begin{array}{l}\text { C1. Ideas creation and } \\
\text { analysis }\end{array}$ & D1. External partnerships & E1. Market \\
\hline A2. Strategic planning & B2. Human capital & C2. Project management & D2. Investment & E2. Sustainability \\
\hline A3. Culture and leadership & $\begin{array}{l}\text { B3. Organisational } \\
\text { competences }\end{array}$ & $\begin{array}{l}\text { C3. IP protection and } \\
\text { management }\end{array}$ & $\begin{array}{ll}\text { D3. Knowledge } \\
\text { management }\end{array}$ & \\
\hline 9 questions & 7 questions & 3 questions & 5 questions & 6 questions \\
\hline
\end{tabular}

Source: COTEC Portugal; see https://www.innovationscoring.pt/apresentacao/conceitos/ with Author's translation into English

To complement the tool, SMEs can also undergo external assessments, receiving feedback from experts. This external assessment gives the possibility of being labelled by COTEC Portugal as an Innovative SME on reaching a certain threshold of innovation management performance. Some 200 SMEs have been recognised in this way in Portugal.

\section{Smart Industry Readiness Index, Singapore Economic Development Board, Singapore}

This tool aims to help SMEs in Singapore to assess their Industry 4.0 maturity in a systematic way. The underlying model and methodology for the assessment was developed with the support of an advisory panel that comprised 21 academic and industry experts. Scores are given to eight criteria within a set of three dimensions: 1) process; 2) technology; 3) organisation (Figure 4.3). These results are combined to calculate an overall Smart Industry Readiness Index value. The performance profiles obtained can guide the SMEs in setting their objectives and priorities and identifying improvement actions to reinforce their use of digital resources to increase their competitiveness.

Figure 4.3. Building blocks of the Smart Industry Readiness Index

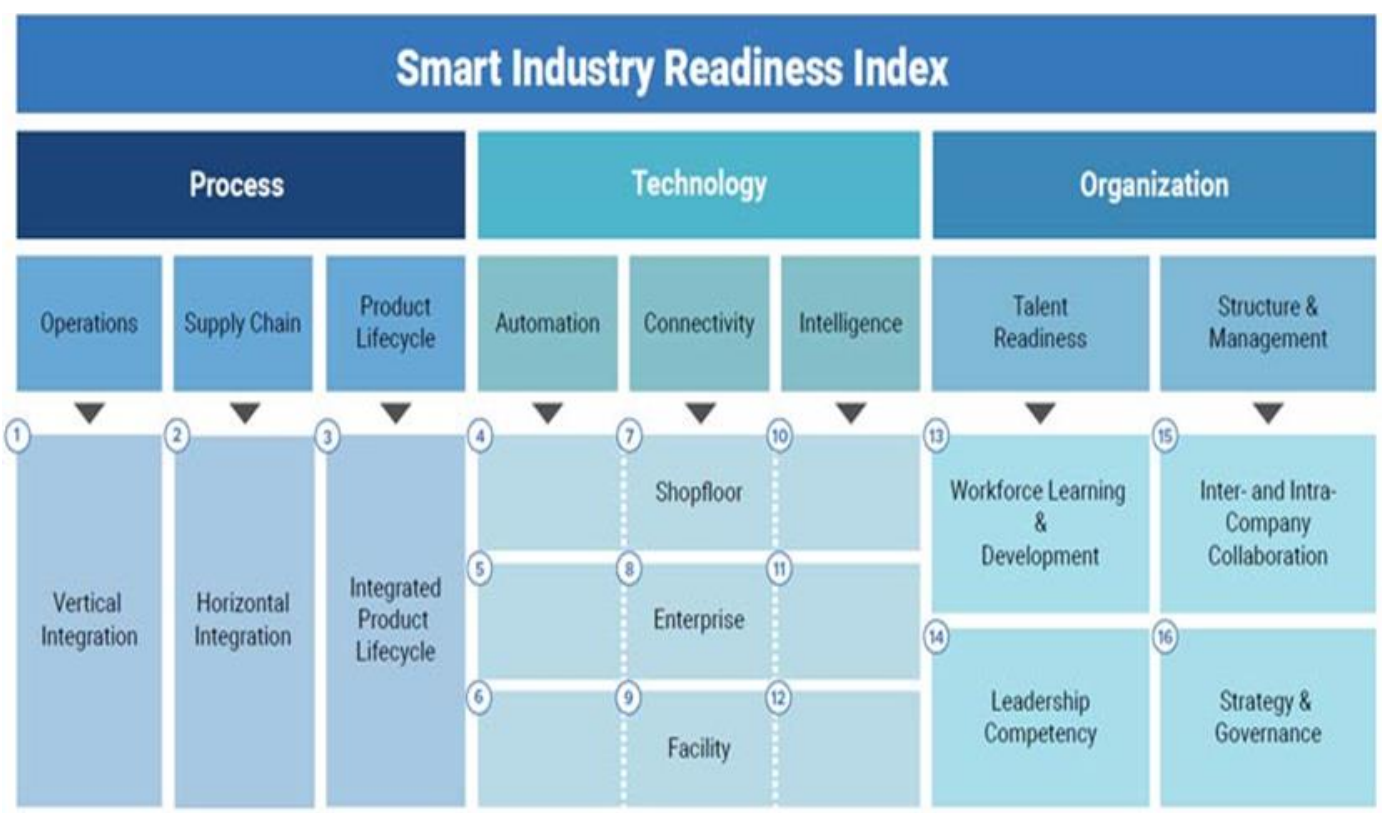

Source: Singapore Economic Development Board; see https://www.edb.gov.sg/en/news-and-resources/news/advanced-manufacturingrelease.html. 


\section{Inno-biz, Korea}

The Korean government's Inno-biz programme includes an online digital tool to support Korean SMEs to assess their technological and innovation performance and define their future priorities. Following an external validation of their capabilities in addressing foreign markets, the firms may be granted a threeyear certificate that provides enhanced access to government technology development, funding and marketing assistance programmes aimed at enabling them to compete globally. Over 3000 SMEs have received this certification.

\section{Intellectual Property Tool, Business Development Bank, Canada}

Many SMEs have excellent business ideas and opportunities but are not smart at protecting them from competitors or other, usually large, organisations. With this in mind, Business Development Bank Canada (BDC) provides SMEs and start-ups with a digital diagnostic tool that allows them to understand how to protect their intangible assets. An online game simulates how ideas can be protected from an intellectual property point of view, thus raising awareness and providing inspiration for more SMEs to consider this possibility and take necessary action.

\section{Internationalisation tools}

\section{The 2SHERPA Network, Singapore}

2SHERPA is a global portal of business consultants and service providers ${ }^{16}$ offering online services, based in Singapore, and with members in 20 countries, including the USA, United Kingdom, Netherlands, Germany, Switzerland, Poland, Finland, Indonesia, Malaysia and China. ${ }^{17}$ The network has developed an online tool that allows SMEs to conduct a benchmarking assessment of their internationalisation capabilities, performance and potential. The partners can make use of the diagnostic tool to offer additional local support to SMEs wanting to move into foreign markets and exports. Over 200 companies use the tool every year, located in Asia, Europe and the USA. The results obtained contribute to a Global Benchmarking Survey updated annually, allowing comparisons to be made between the SMEs using the online tool.

The assessment is conducted based on a total of 350 questions and statements in six areas considered critical for addressing internationalisation issues:

- Defining and executing strategy.

- Identifying and incorporating new legal, financial and ICT requirements.

- Reconfiguring and producing products for a new user market.

- Building or realigning the organisation.

- Effectively understanding and integrating into the target geographical market.

- Building out an effective marketing and sales programme.

SMEs receive and assessment report for each of these six areas.

\section{International Trade Centre (ITC)}

The ITC is a joint agency of the World Trade Organisation and the United Nations focusing on internationalisation of SMEs, including e-business solutions. As part of its support efforts, ITC offers SMEs an online diagnostic of their web presence and, taking this into account, assists them in identifying specific web marketing strategies, e-commerce solutions and relevant e-marketplaces that may contribute to expanding their sales and distribution channels (ITC, 2016). The tool was developed by international e-

\footnotetext{
16 See more: https://www.2sherpa.com/home/

17 E.g. UK-based Lions \& Tigers and The Wundaba Group based in Singapore.
} 
commerce experts and in partnership with a range of large e-commerce firms, such as eBay and DHL, and small specialised firms in related fields, such as legal advisory services.

\section{Bpifrance Internationalisation Metric, France}

Bpifrance's Internationalisation Metric (Mondialomètre) allows SMEs to assess their maturity in exporting or establishing themselves internationally, including market, culture, regulatory aspects and internal resources. The results are linked to support offers and online advice.

\section{Steps to Export, Sweden}

Sweden updated the "Steps to Export" tool in 2018. It is an online tool to help businesses understand what they need to do to trade internationally. It also helps SMEs and start-ups to identify relevant support at the regional export centres (Regionala exportcentrum).

\section{Tools for businesses in difficulty}

\section{Rebounding Companies, Wallonia, Belgium}

The Wallonian regional government launched a new online tool for businesses facing difficulties in 2018. Rebounding Companies (Entreprises en Rebond) was developed to help businesses identify early warning signs of financial difficulties. It can be completed in 15 minutes and SMEs that are concerned about their results can follow-up with one of the scheme's business advisers.

\section{Business Health, Spain}

The Business Health (Salud Empresarial) tool was launched in Spain in 2018 to help prevent the closure of companies. The self-diagnostic tool makes basic recommendations based on the financial information entered.

\section{Supply chain development tools}

\section{Industry Supply Chain Indexes, Australia}

The Industry Supply Chain Indexes are part of the Entrepreneurs' Programme, which supports businesses to improve their competitiveness, productivity, market access, and growth with tailored advice, connections and networking opportunities. It is a facilitated questionnaire-based tool tailored to specific sectors that:

- helps businesses to analyse and ascertain how they fit into a determined supply chain; and

- serves as a readiness indicator for expansion within a determined supply chain.

It comprises a set of industry-specific questions about business capabilities and capacities developed in consultation with key market participants (such as tier 1 purchasers) on what they consider to be crucial factors in supplying their market.

The tool is delivered either one-to-one or one-to-few by Business Advisers as part of the Business Evaluation and Supply Chain Facilitation services in the Entrepreneurs' Programme. The advisers receive training in the subject matter and in the delivery and facilitation of the tool. The results are used to inform an action plan and recommendations for SMEs developed by the advisers in collaboration with the firms.

The following Indexes have been developed:

- Food Industry Supply Chain Index (FISCI)

- Resources Industry Supply Chain Index (RISCI)

- Pharmaceuticals Industry Supply Chain Index (PharmalSCI) 
- Medical Device Technologies Supply Chain Index (MISCI)

- ICT Industry Supply Chain Index (iTISCI)

- Export Capability Tool (ExTool)

No formal evaluation has been undertaken yet. The first Index to be developed was the Resources Industry Supply Chain Index (RISCI) and there was positive feedback from suppliers in the sector that the tool and output were useful. As a result, additional Indexes were developed for other sectors.

One of the challenges faced is that the tool is time-consuming to use (approximately 4-hours) and users find some parts to be complicated. Another challenge is keeping the content current, given changing market conditions.

\section{Brexit readiness}

\section{Brexit SME Scorecard, Ireland}

This interactive online platform tool was launched by the Irish government in 2017 to help Irish businesses identify their exposure to Brexit (the United Kingdom's departure from the European Union and single market and economic area), and the significant market, supply chain, labour availability and other impacts that it may have. The tool generates a report card with six pillars: 1) Business Strategy; 2) Operations; 3) Innovation; 4) Sales and Marketing; 5) Finance; and 6) People Management. Based on the responses, the tool provides suggested actions and resources to help the SMEs to respond to Brexit.

\section{Conclusions and policy recommendations}

Online business diagnostic tools can offer SMEs and start-ups an easy-access, basic assessment of their competitive performance and insights on potential areas for improvement and corresponding actions. In comparison with face-to-face diagnostics, digital tools can be more timely, more affordable, more accessible and easier to use, and offer some meaningful comparisons, visual dashboards and real-time reports.

A variety of tools have been developed and are being actively promoted by governments in a field which is evolving and expanding rapidly. Although they have different scopes of analysis, most of the tools are based on a conceptual model of around 5 to 10 dimensions. The analysis can be based on benchmarking data, or on self-assessment by user firms against typically 40 to 60 questions or statements. These lead to the identification of performance profiles, together with recommendations, priorities and possible areas for improvement. Both generic diagnostic tools relating to overall competitiveness and more specific tools relating to certain dimensions of competitiveness (innovation, internationalisation, digitalisation etc.) are being applied.

A number of private companies have also developed online diagnostic tools, but these tools are not usually accessible to a large number of SMEs due to costs and their proprietary nature. Public policies therefore play an important role in filling gaps in this area.

The following recommendations may be offered to governments and development agencies:

- Promote and publicise digital diagnostic tools. SMEs and start-ups will often lack the resources or skills to research which online diagnostic tools their business may be able to benefit from. Public policies can therefore play a major role in the dissemination of information on relevant tools. In some countries a single, well-known national agency leads these efforts.

- Fill gaps in availability of existing tools. Policy should identify gaps in the tools already accessible and relevant to SMEs and start-ups in given countries. It could then fill these gaps by developing new tools or adapting existing tools to the context of each country. 
- Provide benchmarking data. As more and more data become available for purposes of business performance benchmarking, it is important for policy to promote access to the data of the public administration and to combine different data sources into tools in ways that respect data privacy issues and take into account good practice principles for data management.

- Support users to implement actions related to the diagnostic. It is also important for policy to offer support to SMEs and start-ups to implement actions suggested by the assessments, so as to achieve impacts and incentivise use. It is important to ensure that users understand that the diagnostic is just a starting point and roadmap for the real-life implementation of improvement actions. As well as referring to online case studies and other online guidance, the tools should connect with training, mentoring and consultancy services around the use of the tool, for example with vouchers and brokerage for follow-up services.

- Create guidance to access a collection of existing tools. Policy can create a digital library of publicdomain tools available at the national and international levels, as well as by field of expertise, together with recommendations on how to use them. This would support SMEs and start-ups to navigate the digital business diagnostic tools available. It could be operationalised through a toolbox or library of tools, together with guidance for users on appropriate combinations of tools to access according to their specific goals. It could be seen as an access point to tools that could exist worldwide.

- Creating networking and learning communities. While some pieces of the puzzle may be missing and still need to be completed, globally there are already many digital business diagnostic tools supported by different entities. One of the policy roles is therefore sharing of information across tools and entities, including information on methods and data, and working mutually to increase the visibility of the various tools available to SMEs and start-ups. 


\section{References}

Achtenhagen, L., L. Naldi and L. Melin (2010), "'Business Growth' - Do Practitioners and Scholars Really Talk About the Same Thing?", Entrepreneurship Theory and Practice, Vol. 34, pp. 289-316. doi:10.1111/j.1540-6520.2010.00376.x

Ansoff, I. (1965) Corporate Strategy, Harmondsworth: McGraw-Hill.

Anyadike-Danes, M. and M. Hart (2018), "All grown up? The fate after 15 years of a quarter of a million UK firms born in 1998", Journal of Evolutionary Economics, Vol. 28, pp. 45-76, doi:10.1007/s00191017-0549-x.

Anyadike-Danes, M., M. Hart and J. Du (2015), "Firm dynamics and job creation in the United Kingdom: 1998-2013", International Small Business Journal, Vol. 33, pp. 12-27, doi:10.1177/0266242614552334.

Anyadike-Danes, M., M. Hart and J. Du (2013), "Firm dynamics and job creation in the UK: taking stock and developing new perspectives", University of Warwick, Warwick Business School, Enterprise Research Centre.

Attewell, P. (1992), "Technology Diffusion and Organizational Learning - The Case of Business Computing", Organization Science, Vol. 3, pp. 1-19, doi:10.1287/orsc.3.1.1.

Audretsch, D. B. (2002). Entrepreneurship: A Survey of the Literature: European Commission, Enterprise Directorate General.

Audretsch, D. B. (2004). Sustaining Innovation and Growth: Public Policy Support for Entrepreneurship. Industry and Innovation, 11(3), 167-191.

Audretsch, D. B., Grilo, I., \& Thurik, A. R. (2007). Explaining entrepreneurship and the role of policy: a framework. In D. B. Audretsch, I. Girilo \& A. R. Thurik (Eds.), Handbook of Research on Entrepreneurship Policy (pp. 94-129). Cheltenham: Edward Elgar.

Autio, E. and H. Rannikko (2016), "Retaining winners: Can policy boost high-growth entrepreneurship?", Research Policy, Vol. 45, pp. 42-55.

Awano, G., A. Heffernan and H. Robinson (2017), "Management practices and productivity among manufacturing businesses in Great Britain: Experimental estimates for 2015", available at: https://www.ons.gov.uk/employmentandlabourmarket/peopleinwork/labourproductivity/articles/experi mentaldataonthemanagementpracticesofmanufacturingbusinessesingreatbritain/experimentalestimate sfor2015.

Bager, T. E., Jensen, K. W., Nielsen, P. S. and Larsen, T. A. (2015) Enrollment of SME managers to growth-oriented training programs, International Journal of Entrepreneurial Behavior and Research, 21.4, 578-599.

Bager-Sjögren, L., Gustafsson, O. and Pettersson, L. (2003) "Växtkraft Mål 4 - en effektstudie Kompetensutveckling i små företag" Institutet för Tillväxtpolitiska Studier, ITPS, A2003:001

Banerjee, A., A. V. Banerjee and E. Duflo (2011), "Poor economics: a radical rethinking of the way to fight global poverty", PublicAffairs. 
Baron, J. N., M. T. Hannan and M. D. Burton (1999), "Building the Iron Cage: Determinants of Managerial Intensity in the Early Years of Organizations", American Sociological Review, Vol. 64, pp. 527-547.

Baron, J. N., M.T. Hannan and M. D. Burton (2001), "Labor pains: Change in organizational models and employee turnover in young, high-tech firms", American Journal of Sociology, Vol. 106, pp. 960-1012.

Behavioural Insights Team (2017), "Be the business; boosting productivity in the UK", available at: http://www.behaviouralinsights.co.uk/news/be-the-business-boosting-productivity-in-the-uk/.

Bennett, R. J. and P. Robson (2003), "Changing use of External Business Advice and Government Supports by SMEs in the 1990s", Regulatory Studies, Vol. 37, pp. 795-811, doi:Doi $10.1080 / 0034340032000128721$.

Bennett, R. J. and P. J. A. Robson (1999), "Intensity of Interaction in Supply of Business Advice and Client Impact: A Comparison of Consultancy, Business Associations and Government Support Initiatives for SMEs", British Journal of Management, Vol. 10, pp. 351-369, doi:10.1111/14678551.00144 (1999).

Bennett, R. J. and P. J. A. Robson (2004), "The Role of Trust and Contract in the Supply of Business Advice”, Cambridge Journal of Economics, Vol. 28, pp. 471-488, doi:Doi 10.1093/Cje/Beh021.

Bennett, R.J. (2014), Small Business and Public Policy: Evolution and Revolution, Routledge.

Bennett, R.J. and C. Smith (2002), "The Influence of Location and Distance on the Supply of Business Advice", Environment and Planning A, Vol. 34, pp. 251-270, doi: 10.1068/A34136.

Bergek, A. and Norrman, C. (2015) Integrating the supply and demand sides of public support to new technology-based firms, Science and Public Policy, 42, pp. 514-529.

Bloom, N. and J. Van Reenen (2010), "Why Do Management Practices Differ across Firms and Countries?", Journal of Economic Perspectives, Vol. 24, pp. 203-224, doi:10.1257/jep.24.1.203.

Bloom, N. and J. Van Reenen (2007), "Measuring and Explaining Management Practices Across Firms and Countries", Quarterly Journal of Economics, Vol. 122, pp. 1351-1408.

Bloom, N., B. Eifert, A. Mahajan, D. McKenzie and J. Roberts (2013), "Does management matter? Evidence from India", The Quarterly Journal of Economics, Vol. 128, pp. 1-51.

Boon, S. and M. Ram (1998), "Implementing quality in a small firm - An action research approach", Personnel Review, Vol. 27, pp. 20-.

Bourke, J. and S. Roper, (2016), " AMT adoption and innovation: An investigation of dynamic and complementary effects", Technovation, Vol. 55-56, pp. 42-55, doi:10.1016/j.technovation.2016.05.003.

Bourke, J. and S. Roper (2017), "Innovation, quality management and learning: Short-term and longerterm effects”, Research Policy, Vol. 46, pp. 1505-1518, doi:10.1016/j.respol.2017.07.005.

Braunerhjelm, P., \& Henrekson, M. (2012) Ett ramverk för innovationspolitiken: Hur göra Sverige mer entreprenöriellt? Samhällsförlaget.

Brown, R., Mawson, S. and Mason, C. (2017) Myth-busting and entrepreneurship policy: the case of high growth firms, Entrepreneurship \& Regional Development, 29:5-6, 414-443.

Campos, F., Frese, M., Goldstein, M., lacovone, L., Johnson, H., McKenzie, D. and Mensmann, M. (2017), "Teaching personal initiative beats traditional training in boosting small business in West Africa", Science, Vol. 357, pp. 1287-1290, doi:10.1126/science.aan5329.

Cassell, C., S. Nadin and M. Gray (2001), "The use and effectiveness of benchmarking in SMEs", Benchmarking: An International Journal, Vol. 8, pp. 212-222.

Chadwick, C., J. F. Super and K. Kwon (2015), "Resource orchestration in practice: CEO emphasis on SHRM, commitment-based HR systems, and firm performance", Strategic Management Journal, Vol. 36, pp. 360-376, doi:10.1002/smj.2217. 
Chrisman, J. J. and W. E. McMullan (2004), "Outsider assistance as a knowledge resource for new venture survival”, Journal of Small Business Management, Vol. 42, pp. 229-244.

Clark, T. \& Fincham, R. (2002),(Blackwell, Oxford).

Coad, A., Frankish, J., Roberts, R. G., \& Storey, D. J. (2013). Growth paths and survival chances: An application of Gambler's Ruin theory. Journal of Business Venturing, 28(5), 615-632. doi:https://doi.org/10.1016/i.jbusvent.2012.06.002

Cohen, W.M. and D.A. Levinthal (1990), "Absorptive Capacity: A New Perspective on Learning and Innovation", Administrative Science Quarterly, Vol. 35, pp. 128-152.

Committee of Donor Agencies for Small Enterprise Development (2001), Business Development Services for Small Enterprises: Guiding Principles for Donor Intervention, World Bank Group, Washington DC, https://www.enterprise-development.org/wp-content/uploads/BDS-GuidingPrinciples-2001-English.pdf/

Davidsson, P., Delmar, F., \& Wiklund, J. (2006). Entrepreneurship and the Growth of Small Firms. Cheltenham: Edward Elgar

Derbyshire, J., \& Garnsey, E. (2014). Firm growth and the illusion of randomness. Journal of Business Venturing Insights, 1-2, 8-11. doi:https://doi.org/10.1016/j.jbvi.2014.09.003

Drews, C.-C. and M. Hart (2015), "Feasibility Study - Exploring the Long-Term Impact of Business Support Services", Aston Business School, Birmingham.

Drexler, A., G. Fischer and A. Schoar (2004), "Keeping it simple: financial literacy and rules of thumb", American Economic Journal: Applied Economics, Vol. 6, pp. 1-31.

Dyer, L. M. and C. A. Ross (2007), "Advising the small business client", International Small Business Journal, Vol. 25, pp. 130-151, doi:10.1177/02662426607074517.

European Commission (2019) 2019 SBA Fact Sheet, European Commission, Brussels.

European Commission (2011), "Policies in support of high-growth innovative SMEs", An INNO-Grips Policy Brief by empirica Communication and Technology Research, Bonn.

European Commission (2010), 'Software program for a global approach to the crafts/artisan business', Small Business Act, European Commission, available at:

https://webgate.ec.europa.eu/good practice/sba/index.cfm?fuseaction=practice.detail\&gp pk=8570\&t $\underline{\mathrm{r} p \mathrm{pk}=6550}$

Feeser, H. and G. Willard (1990), "Founding strategy and performance: A comparison of High and Low Growth high Tech Firms", Strategic Management Journal, Vol. 11, pp. 87-98.

Flamholtz, E. and Y. Randle (1990), "Growing pains: How to make the transition from an entrepreneurship to a professionally managed firm", Jossey-Bass Inc Pub.

Flamholtz, E. G. (2003), "Putting balance and validity into The Balanced Scorecard", Journal of Human Resource Costing \& Accounting, Vol. 7, pp. 15-26.

Forenklingsudvalget for erhvervsfremme. (2018). Fokuseret og fremtidssikret. Retrieved from https://em.dk/media/9769/18-04-06-erhvervsfremmeudvalgets-rapport-fokuseret-og-fremtidssikret.pdf

Frankelius, P. (2009) Questioning two myths in innovation literature, Journal of High Technology Management Research, vol. 20.1, s. 40-51.

Frankelius, P. and Norrman, C. (2013) Uppfinningars betydelse för Sverige, Vinnova Rapport, VR2013:03

Frankelius, P., Norrman, C., and Johansen, K. (2017) Agricultural Innovation and the Role of Institutions: Lessons from the Game of Drones, Journal of Agriculture and Environmental Ethics, (Published online 29 December 2017)

Fraser, S., D. Storey, J. Frankish and R. Roberts (2002), "The Relationship Between Training and Small Business Performance: An Analysis of the Barclays Bank Small Firms Training Loans Scheme," 
Environment and Planning C: Politics and Space, Vol. 20, pp. 211-233, doi:10.1068/c0111.

Gault, F. (2013) Handbook of Innovation Indicators and Measurement, Edward Elgar; Cheltham, UK Northampton, MA, USA.

Gramtorp, A. (2018). I krydsfeltet mellem passion og cool cash. (Ph.d), University of Southern Denmark.

Greene, F., K. Mole and D. Storey (2008), "Three Decades of Enterprise Culture: Entrepreneurship", Economic Regeneration and Public Policy, Palgrave.

Haltiwanger, J.C., J.I. Lane, and J.R. Spletzer (2000), Wages, Productivity and the Dynamic Interaction of Businesses and Workers, Cambridge, MA.

Huselid, M.A. (1995), "The impact of human resource management practices on turnover, productivity, and corporate financial performance", Academy of Management Journal, Vol. 38, pp. 635-672.

Ichniowski, C. and K. Shaw (1999), "The effects of human resource management systems on economic performance: An international comparison of US and Japanese plants", Management Science, Vol. 45, pp. 704-721.

Ichniowski, C., K. Shaw and G. Prennushi (1997), "The effects of human resource management practices on productivity: A study of steel finishing lines”, American Economic Review, Vol. 87, pp. 291-313.

Ingstrup, M. B., Damgaard, T. M., \& Evald, M. R. (2017). Tre pejlemærker for fremtidens danske erhvervsfremmesystem. Mandag Morgen (online) (35).

IRIS Group (2013), Evaluering af væksthusene. Retrieved from https://irisgroup.dk/wpcontent/uploads/2018/03/Evaluering-af-V\%C3\%A6ksthusene-april-2013.pdf

Johnson, S., D.J. Webber and W. Thomas (2007), "Which SMEs use External Business Advice? A Multivariate Subregional Study", Environment and Planning A, Vol. 39, pp. 1981-1997, doi: $10.1068 / \mathrm{A} 38327$.

Jones, O., R. Thorpe, A. MacPherson, and R. Holt (2008) in The Evolution of Business Knowledge (ed H. Scarborough), Oxford University Press, pp. 23-50.

Jovanovic, B. (1982), "Selection and the Evolution of Industry", Econometrica, Vol. 50, pp. 649-670.

Kaplan, R. S. and D. P. Norton (1982), "The balanced scorecard - measures that drive performance", Harvard Business Review, Vol. 70, pp. 71-79.

Klofsten, M. (1992) Early Development Processes in Technology Based Firms, Linkoping Studies in Management and Economics, No. 24, Linkoping, Sweden.

Klofsten, M. and Jones-Evans, D. (2013) Open learning with growing businesses, European Journal of Training and Development, vol 37, no 3, pp. 298-312.

Klofsten, M. \& Norrman, C. (2013) An Integrated Approach to Measuring the Development of High Technology Firms in High Technology Entrepreneurship, A Festschrift for Ray Oakey, University Press.

Lambrecht, J. and F. Pirnay (2005), "An evaluation of public support measures for private external consultancies to SMEs in the Walloon Region of Belgium", Entrepreneurial Regional Development, Vol. 17, pp. 89-108, doi:10.1080/0898562042000338598.

Lee, N. (2014), "What holds back high-growth firms? Evidence from UK SMEs", Small Business Economics, Vol. 43, pp. 183-195, doi:10.1007/s11187-013-9525-5.

Lipsky, M. (2010), "Street Level Bureaucracy: Dilemmas of the Individual in Public Services", 30th Anniversary Expanded Edition, The Russell Sage Foundation.

Lundström, A., \& Stevenson, L. (2002). On the Road to Entrepreneurship Policy (Vol. 1). Stockholm: FSF.

Lundström, A., \& Stevenson, L. (2005). Entrepreneurship Policy: Theory and Practice: Springer, USA. 
Madaleno, M. and S. Waights (2018), "Guide to scoring methods using the Maryland Scientific Methods Scale", available at: http://www.whatworksgrowth.org/public/files/Scoring-Guide.pdf.

Mason, C. and R. Brown (2013), "Creating good public policy to support high-growth firms", Small Business Economics, Vol. 40, pp. 211-225, doi:10.1007/s11187-011-9369-9.

McKelvey, M. and Zaring, O. (2016) "Hur ett Schumpeterianskt perspektiv kan leda till bättre innovationspolitik", in McKelvey, M. and Zaring, O. Sveriges entreprenöriella ekosystem - företag, akademi, politik, (Stockholm: Esbri)

McKenzie, D. and C.M. Woodruff (2015), "Business practices in small firms in developing countries", Working Paper 21505, NBER Working Paper Series, National Bureau of Economic Research, Cambridge MA.

McKinsey and Company, Struensee and Co, Damvad Analytics, and Landfall Strategy Group (2016). Eftersyn af Erhvervsfremmeindsatsen. Report for Ministry of Trade and Industry, Denmark. Retrieved from https://em.dk/nyhedsarkiv/2016/november/analyse-af-erhvervsfremmesystemet-er-klar/

Miehlbradt, A. O. (2002), "Assessing markets for business development services: what have we learned so far?", Small Enterprise Development, Vol. 13, pp. 54-66.

Mole, K. and J.L. Capelleras (2018), "Take-up and variation of advice for new firm founders in different local contexts", Environment and Planning C: Politics and Space, Vol. 36.1, pp. 3-27.

Mole, K. F., M. Hart and S. Roper (2014), "When moving information online diminishes change: advisory services to SMEs", Policy Studies, Vol. 35, pp. 172-191, doi:10.1080/01442872.2013.875145.

Mole, K. F., M. Hart, S. Roper and D. Saal (2011), "Broader or deeper? Exploring the most effective intervention profile for public small business support, Environment and Planning A, Vol. 43, pp. 87105.

Mole, K., M. Hart and D. Saal (2008), "Differential Gains from Business Link Support and Advice: A Treatment Effects Approach", Environment and Planning C-Government and Policy, Vol. 26, pp. 315334, doi:10.1068/c0711.

Mole, K., D. North and R. Baldock (2017), "Which SMEs seek external support? Business characteristics, management behaviour and external influences in a contingency approach", Environment and Planning C-Politics and Space, Vol. 35, pp. 476-499, doi:10.1177/0263774×16665362.

NESTA (2017), Innovation Growth Lab, http://innovationgrowthlab.org/our-projects.

Nielsen, P. S., Jensen, K. W., and Bager, T. (2018). SMV'er på skolebænken. In K. Klyver, P. R. Christensen, \& P. V. Freytag (Eds.), De mørke sider af ledelse og drift af mindre virksomheder (pp. 15-24): Syddansk Universitetsforlag

Nightingale, P. and A. Coad (2013), "Muppets and gazelles: political and methodological biases in entrepreneurship research", Industrial and Corporate Change, Vol. 23, pp. 113-143, doi:10.1093/icc/dtt057.

Norrman, C. (2008), "Entrepreneurship policy: public support for technology-based ventures", Linköping studies in Science and Technology, Avhandling nr 1175), Linköping (se även http://libris.kb.se/bib/10874422)

North, D., and Smallbone, D. (2012), Targeting established SMEs: Does their age matter? International Small Business Journal, 13, 3, pp. 47-64.

North, D., Smallbone, D., \& Vickers, I. (2001). Public Sector Support for Innovating SMEs. Small Business Economics, 16, 303-317.

OECD (2020) An OECD Strategy for SMEs: Review of SME and Entrepreneurship Typologies from the Literature, OECD Official Document, Paris (CFE/SME(2019)7/ANN2.

OECD (2017), "Going Digital: Making the Transformation work for Growth and Well-Being", Meeting of the OECD Council at Ministerial Level, OECD, June 2017. https://www.oecd.org/mcm/documents/C- 


\section{MIN-2017-4\%20EN.pdf}

OECD (2013), "An international benchmarking analysis of public programmes for high-growth firms", Prepared by the OECD Local Economic and Employment Development Programme in collaboration with the Danish Business Authority, Paris.

OECD (2007) OECD Framework for Evaluation of SME and Entrepreneurship Policies and Programmes, OECD Publishing, Paris.

OECD/Eurostat (2005) Oslo Manual: Guidelines for Collecting and Interpreting Innovation Data, third ed.

Okhuysen, G. A. and K. M. Eisenhardt (2002), "Integrating knowledge in groups: How formal interventions enable flexibility", Organization Science, Vol. 13, pp. 370-386.

Patel, P. C. and M. S. Cardon (2010), "Adopting HRM practices and their effectiveness in small firms facing product-market competition”, Human Resource Management, Vol. 49, pp. 265-290, doi:10.1002/hrm.20346.

Philipsson, M. (2018), Personal communication 2018-04-20is beside his role as CEO of Almi Östergötland also engaged in the development of the parent company.

Piza, C. et al. (2016), "The Impact of Business Support Services for Small and Medium Enterprises on Firm Performance in Low- and Middle-Income Countries: A Systematic Review", available at: http://documents.worldbank.org/curated/en/521211467989461591/The-impact-of-business-supportservices-for-small-and-medium-enterprises-on-firm-performance-in-low-and-middle-income-countriesa-meta-analysis.

Reichheld, F. F. (2003), "The One Number You Need to Grow”, Harvard Business Review, Vol. 81, pp. 46-54.

Rice, M. P. (2002), "The co-production of business assistance in business incubators: An exploratory study", Journal of Business Venturing, Vol. 17, pp. 163-187.

Roper, S., J. Love and K. Bonner (2017), "Firms' knowledge search and local knowledge externalities in innovation performance", Research Policy, Vol. 46, pp. 43-56.

Rosenbloom, R. S. and Christensen, C. M. (1994) Technological discontinuities, organizational capabilities, and strategic commitments, Industrial and Corporate Change, 3: 655-85.

Sawang, S., R. Parker and D. Hine (2016), "How Small Business Advisory Program Delivery Methods (Collective Learning, Tailored, and Practice-Based Approaches) Affect Learning and Innovation", Journal of Small Business Management, Vol. 54, pp. 244-261.

Schumpeter, J. A. (1934). The Theory of Economic Development. Cambridge, Mass: Harvard University Press.

Seo, J. H., Perry, V. G., Tomczyk, D., \& Solomon, G. T. (2014). Who benefits most? The effects of managerial assistance on high- versus low-performing small businesses. Journal of Business Research, 67(1), 2845-2852. doi:https://doi.org/10.1016/j.jbusres.2012.07.003

Sels, L. et al. (2006), "Unravelling the HRM-Performance link: Value-creating and cost-increasing effects of small business HRM", Journal of Management Studies, Vol. 43, pp. 319-342.

Shane, S. (2003). A General Theory of Entrepreneurship: The Individual-Opportunity Nexus. Cheltenham: Edward Elgar.

Sheehan, M. (2013), "Human resource management and performance: Evidence from small and medium-sized firms”, International Small Business Journal, doi:10.1177/0266242612465454.

Siegel, R., E. Siegel and I. C. Macmillan (1993), "Characteristics distinguishing high-growth ventures", Journal of Business Venturing, Vol. 8, pp. 169-180.

Smallbone, D., R. Baldock and S. Burgess (2002), "Targeted Support for High-Growth Start-ups: Some Policy Issues", Environment and Planning C, Vol. 20, pp. 195-209.

Spence, M. (1973), “Job Market Signaling”, Quarterly Journal of Economics, Vol. 87, pp. 355-374. 
Stevenson, H., Hoch C. J. Jarillo (1990): A paradigm of Entrepreneurship: Entrepreneurial management, Strategic Management Journal, vol. 11, 17-27.

Stevenson, L. \& Lundström, A. (2007). Dressing the emperor: the fabric of entrepreneurship policy. In D. B. Audretsch, I. Girilo \& A. R. Thurik (Eds.), Handbook of Research on Entrepreneurship Policy, pp. 94-129, Cheltenham: Edward Elgar.

Storey, D. J. (1994), Understanding the Small Business Sector, Routledge.

Thaler, R. H. and C. R. Sunstein (2008), Nudge: Improving Decisions about Health, Wealth, and Happiness, Yale University Press.

Tracey, P. and O. Jarvis (2007), "Toward a theory of social venture franchising”, Entrepreneurship Theory and Practice, Vol. 31, pp. 667-685.

Van de Ven, A. H. and M. S. Poole (1995), "Explaining development and change in organizations", Academy of management review, Vol. 20, pp. 510-540.

van Doorn, S., M.L. Heyden and H.W. Volberda (2016), "Enhancing Entrepreneurial Orientation in Dynamic Environments: The Interplay between Top Management Team Advice-Seeking and Absorptive Capacity", Long Range Planning, Vol. 50, pp. 134-144.

What Works Centre for Local Economic Growth (2014) "Evidence Review : Business Advice", London School of Economics, London.

Wiklund, J., Davidsson, P., \& Delmar, F. (2003). What Do They Think and Feel about Growth? An Expectancy-Value Approach to Small Business Managers' Attitudes Toward Growth.

Entrepreneurship: Theory \& Practice, 27(3), 247-271

Wolff, J. A., Pett, T. L. and Ring, J. K. (2015) "Small firm growth as a function of both learning orientation and entrepreneurial orientation: An empirical analysis", International Journal of Entrepreneurial Behavior \& Research, Vol. 21 Issue: 5, pp.709-730.

Wren, C. and D.J. Storey (2002), "Evaluating the Effect of Soft Business Support upon Small Firm Performance", Oxford Econ Paper No. 54, pp. 334-365.

Zahra, S.A. and G. George (2002), "Absorptive capacity: a review, re-conceptualization, and extension", Academy of Management Review, Vol. 27, pp. 185-203. 